(2) norden 



\section{Internationaliseringen av de nordiska arbetsmarknaderna och dess konsekvenser för arbetskraftsefterfrågan}

Tor Eriksson

TemaNord 2008:552 
Internationaliseringen av de nordiska arbetsmarknaderna och dess konsekvenser för arbetskraftsefterfrågan

TemaNord 2008:552

(C) Nordiska ministerrådet, Köpenhamn 2008

ISBN 978-92-893-1701-6

Tryck: Ekspressen Tryk \& Kopicenter

Upplaga: 90

Tryckt på miljövänligt papper som uppfyller kraven i den nordiska miljösvanemärkningen.

Publikationen kan beställas på www.norden.org/order. Fler publikationer på

www.norden.org/publikationer

Printed in Denmark

Nordiska ministerrådet

Store Strandstræde 18

DK-1255 Köpenhamn K

Telefon $(+45) 33960200$

Fax (+45) 33960202

www.norden.org

\section{Nordiska rådet}

Store Strandstræde 18

DK-1255 Köpenhamn K

Telefon (+45) 33960400

Fax (+45) 33111870

\section{Det nordiska samarbetet}

Det nordiska samarbetet är ett av världens mest omfattande regionala samarbeten. Det omfattar Danmark, Finland, Island, Norge och Sverige samt de självstyrande områdena Färöarna, Grönland och Åland.

Det nordiska samarbetet är politiskt, ekonomiskt och kulturellt förankrat och är en viktig partner i europeiskt och internationellt samarbete. Den nordiska gemenskapen arbetar för ett starkt Norden i ett starkt Europa.

Det nordiska samarbetet vill styrka nordiska och regionala intressen och värderingar i en global omvärld. Gemensamma värderingar länderna emellan bidrar till att stärka Nordens ställning som en av världens mest innovativa och konkurrenskraftiga regioner. 


\section{Content}

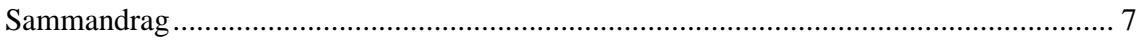

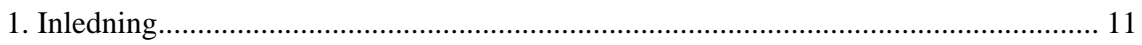

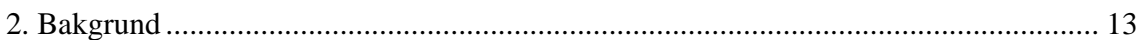

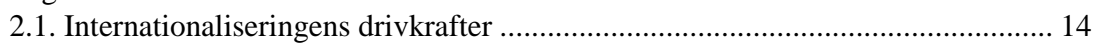

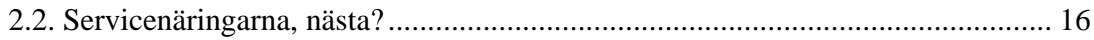

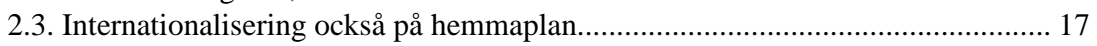

3. Mycket kort om vad ekonomisk teori säger................................................................ 21

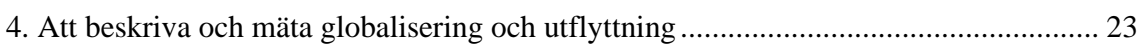

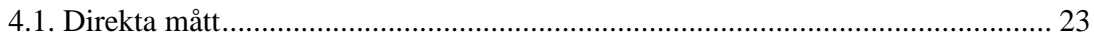

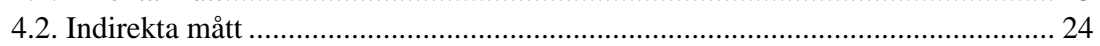

5. Utflyttningens konsekvenser - tidigare forskning .................................................... 27

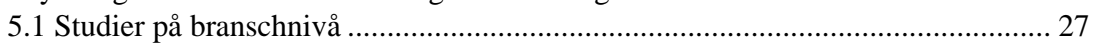

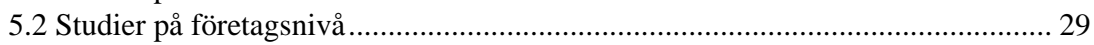

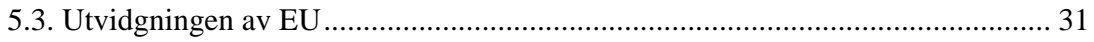

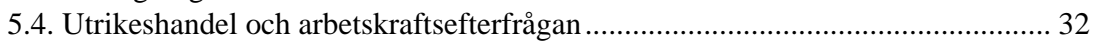

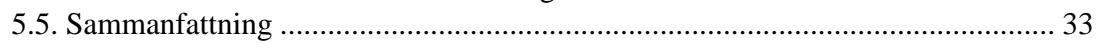

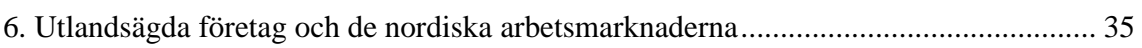

6.1 Utlandsägda versus inhemska företag .............................................................. 35

6.2 Konsekvenserna av utländska företagsuppköp ..................................................... 39

7. Utflyttning av produktion - konsekvenser för sysselsättning och löner ...................... 45

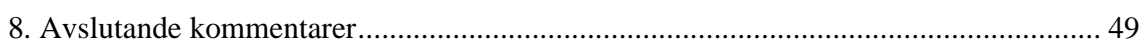

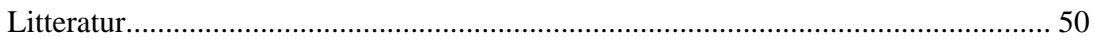





\section{Sammandrag}

Under de två senaste decennierna har stora förändringar i den internationella handeln ägt rum. Ur en nordisk synvinkel är det i synnerhet två förändringar som är viktiga: utvidgningen av EU till att omfatta de tidigare planekonomierna i central- och öst-Europa och integrationen av de stora och starkt växande ekonomierna i öst-Asien. Ett centralt element i världshandelns utveckling har varit den snabbt växande handeln med mellanprodukter. Denna tillväxt återspeglar en tendens till ökad fragmentering företagens värdekedjor. Parallellt med dessa förändringar har även de utländskt ägda företagens andel vuxit snabbt i de nordiska länderna.

Föreliggande rapport har två syften. Dels ger den en översikt av det forskningsbaserade kunskapsläget rörande effekterna av internationaliseringen på sysselsättning, arbetskraftsefterfrågans struktur samt löner, dels sammanfattar den centrala resultat från ett projekt "Internationaliseringen av de nordiska arbetsmarknaderna och dess konsekvenser för arbetskraftsefterfrågan" vilket initierats och finansierats av Nordiska Minsterrådets arbetsmarknadsutskott. I rapporten diskuteras vidare de problem som är förknippade med att studera internationaliseringen av arbetsmarknaderna och vad man kan göra för att förbättra kunskapsläget.

Diskussionen om internationalisering/globalisering handlar vanligtvis om utflyttning av produktion och arbetsplatser. Vad som därvidlag ofta förbises är att när våra ekonomier blir allt mera integrerade i världsekonomin så betyder det samtidigt att företag och arbetsplatser i våra egna länder också blir mera internationella i så måtto att de i stigande grad får utländska ägare. Internationaliseringen är med andra ord inte en enkelriktad gata och en intressant fråga är hur detta påverkar arbetsmarknaderna på hemmaplan. Vidare är debatten något ensidig i det avseendet att den så gott som uteslutande fokuserar på att utflyttning av produktion till låglöneländer. En betydande del av de nordiska multinationella företagens aktiviteter utanför Norden motiveras av närhet till gamla och nya marknader, teknologiskt kunnande samt andra faktorer än låga lönekostnader. Följaktligen innebär inte alla internationella aktiviteter ett hot mot jobben i hemländerna, snarare tvärtom.

Hittills har debatten huvudsakligen gällt industrin. Men industrins andel av BNP är typiskt mindre än 15 procent i vår typ av länder och med tanke på framtiden är det nog minst lika viktigt att skapa sig en bild av vad som sker med arbetsplatser och löner inom servicesektorerna. Olika försök att uppskatta förändringarnas omfattning i tjänstesektorn är förknippade med betydande osäkerhet men tyder sammantagna på att antalet jobb som kan utflyttas kan bli avsevärt större än vad man tidigare har föreställt sig. Sålunda pekar några mera detaljerade amerikanska studier- 
na på att mellan 30 och 40 procent av jobben inom tjänstesektorerna (i USA) kan bli föremål för utflyttning till andra länder.

Det faktamässiga grundlaget för vad vi vet om internationalisering av produktion och arbetsmarknad är rätt bristfälligt. Möjligheterna att bedriva forskning om, liksom även bevakning av, internationaliseringen av företag och arbetsmarknader begränsas i hög grad av bristen på relevanta datamängder. Denna avspeglar i sin tur den offentliga statistikproduktionens utpräglat nationella karaktär.

Den empiriska forskningen har hittills huvudsakligen grundat sig sig på indikatorer som beskriver utflyttning av företagens aktiviteter med hjälp av aggregerad information, vanligen på branschnivå. De flesta av studierna visar att utflyttning av produktion och uppgifter leder till en ökad efterfrågan på mera kvalificerad arbetskraft samtidigt som sysselsättningsutsikterna för den okvalificerade arbetskraften försämras. Även löneskillnaderna mellan kvalificerad och okvalificerad arbetskraft tenderar att växa. För de europeiska, inklusive de nordiska, länderna är effekterna dock relativt små. De verkligt stora effekterna av utflyttning av industriproduktion till Kina finner man i de asiatiska grannländerna (i synnerhet inom industrin) och förmodligen även i Kinas främsta konkurrentländer såsom Mexiko, Latin-Amerika och Ryssland.

Det finns överraskande få undersökningar om effekterna av den ökade konkurrensen från de nya marknadsekonomierna i central- och östEuropa samt av utvidgningen av EU. Evidensen är rätt blandad; tidigare undersökningar fann positiva effekter på de gamla EU-länderna medan nyare studier pekar på klart mindre positiva och till och med negativa sysselsättningseffekter. Det bör dock understrykas att antalet studier om detta är få till antalet.

Den empiriska forskningen som utnyttjar information om företagens internationalisering vilken insamlats på företagsnivå ger också rätt varierande resultat. Ett genomgående mönster är dock att medan tidigare studier fann positiva effekter på sysselsättningen i hemmaföretaget så finner nyare undersökningar som även inkluderar ändringarna under det senaste decenniet mindre positiva, och ofta även negativa, effekter av utflyttningen på sysselsättning och löner i hemmaföretaget. Det ovansagda gäller även för de studier som utförts som en del av det aktuella projektet.

Utlandsägda företag i Norden skiljer sig från de inhemska företagen på motsvarande sätt som i andra utvecklade ekonomier: de är större, uppvisar högre produktivitet samt betalar sina anställda högre löner. De uppfattas därför som synnerligen attraktiva arbetsplatser. Analyser som genomförts av projektdeltagarna dokumenterar dock att utlandsägda företag inte betalar en särskild lönepremie till sina anställda. Den högre lönen relativt de inhemska företagen beror på att de utlandsägda företagen anställer medarbetare med högre kvalifikationer och utbildning än inhemska företag. En viktig insikt från de genomförda analyserna är att de utländska multinationella företagen inte skiljer sig nämnvärt från de inhemska 
multinationella företagen med avseende på hur de avlönar sina anställda, arbetskraftens kvalifikationsstruktur, m.m. Den centrala skiljelinjen går mellan multinationella och icke multinationella företag, inte mellan inhemska och utlandsägda företag.

Hur det växande utländska ägandet påverkat arbetsmarknaderna är dock alltjämt en öppen fråga. Nyare forskningsresultat tyder på att en av följderna kan vara något större löneskillnader, speciellt i den övre ändan av den företagsinterna lönefördelningen.

En annan konsekvens som diskuterats i arbetsmarknadsdebatten är vad ett ökat utlandsägande betyder för osäkerheten i antällningarna. Det finns emellertid inget helt entydigt svar på frågan huruvida ett ökat antal uppköp av nordiska företag innebär att arbetskraftsefterfrågan blir mer elastisk och därmed skapar ökad otrygghet för de anställda. De fåtaliga nordiska studierna tyder faktiskt på att det här förhåller sig antingen omvänt (dvs. efterfrågeelasticiteten är lägre i de utlandsägda företagen) eller så finns det ingen skillnad mellan inhemska, utlands- och inhemskt ägda multinationella företag.

En annan fråga av intresse är om de utländska företagen har positiva spillover-effekter på de inhemska företagen och deras anställda. Detta är i många länder ett av huvudargumenten för att locka till sig utländska investerare och företagsetableringar. Resultaten i den internationella litteraturen varierar mycket medan de nordiska bidragen, som är synnerligen få till antalet, målar en entydigt positiv bild. Mera precist visar de att arbetstagare med erfarenhet av arbete i ett mutinationellt företag erhåller en högre lön (och uppvisar högre produktivitet) vid anställningar i inhemska företag. Detta indikerar att det kan finnas positiva spillover-effekter i de nordiska länderna. Att man inte lika entydigt funnit belägg för dessa i andra länder kan t.ex. bero på att spillover-effekter av ovannämnd typ förutsätter en högre utbildningsnivå hos arbetskraften.

Resultaten från forskningen om utflyttningens konsekvenser för sysselsättningen i hemmaföretaget eller för den lokala arbetsmarknaden pekar i rätt olika riktningar. Det kan bero på att effekterna ändrar sig över tiden allt eftersom utflyttningens drivkrafter och därmed destinationer (och form) ändrar sig. Ett mönster som kan skönjas i den nyare forskningen, och som även finner stöd $i$ våra egna bidrag, är att de positiva sysselsättningseffekterna i hemlandet med tiden har blivit mindre och under den senaste tiden till och med blivit negativa.

Sammanfattningsvis tyder vår genomgång av den empiriska forskningslitteraturen liksom våra egna undersökningar på att effekterna i de nordiska länderna är av förhållandevis blygsam storlek. Effekterna på sysselsättning och löner är inte entydigt negativa eller positiva men återspeglar skillnaderna i internationaliseringens karaktär, drivkrafter och former mellan olika branscher. Detta innebär att anpassningsprocesserna inom vissa sektorer kan bli smärtsamma och de samhällsekonomiska kostnaderna betydande. Sociala skyddsnät i kombination med arbets- 
marknadsinstitutioner som medverkar att underlätta strukturomvandlingsprocesserna kan även i fortsättningen bidraga till att de nordiska länderna deltar i den internationella ekonomiska integrationen utan att detta skapar stora problem och att denna utveckling stöds av stora delar av befolkningen. 


\section{Inledning}

Föreliggande rapport sammanfattar de centrala resultaten av projektet "Internationaliseringen av de nordiska arbetsmarknaderna och dess konsekvenser för arbetskraftsefterfrågan” vilket initierats och finansierats av Nordiska Minsterrådets arbetsmarknadsutskott. Dessutom innehåller rapporten en översikt av det forskningsbaserade kunskapsläget på området med tonvikt på forskning och erfarenheter från Europa och de nordiska länderna i synnerhet.

Projektet har haft två övergripande syften. Det första syftet är att undersöka hur sysselsättning, arbetskraftsefterfrågans sammansättning och lönerna påverkas av ett ökat utlandsägande i Norden. Den andra centrala frågeställningen är att studera följderna på de nordiska arbetsmarknaderna av outsourcing och utflyttning av produktion till andra länder och framför allt länder med väsentligt lägre löner. För dessa ändamål har projektdeltagarna analyserat så kallade länkade datamängder vilka innehåller detaljerad information om såväl företaget som dess anställda. En stor fördel med denna typ av analyser är att det gör det möjligt för forskarna att ta hänsyn till att det finns betydande skillnader mellan företagen med avseende på deras personal. Som framgår av rapporten försvåras emellertid forskningen om företagens internationalisering och dess arbetsmarknadskonsekvenser i hög grad av bristen på adekvata data för ändamålet. Detta har också utgjort ett problem i projektet. Det har heller inte varit möjligt, villket annars ofta är fallet i Norden, att utnyttja likheterna i datamängder för en närmare jämförelse av de nordiska länderna.

Deltagarna i projektet har kommit från Danmark, Finland och Sverige. De svenska projektdeltagarna, Fredrik Heyman och Patrik Gustavsson Tingvall var ursprungligen anknutna till Fackföreningsrörelsens Institut för Ekonomomisk Forskning (FIEF) men flyttade efter dess nedläggelse till Institutet för Närinsglivsforskning (IFN) respektive Handelshögskolan i Stockholm. Den finländska projektdeltagaren, Edvard Johansson var vid projektets start anställd vid Näringslivets ekonomiska forskningsinstitut (ETLA), sedan i en period vid Svenska Handelshögskolan i Helsingfors, men har nu återvänt till ETLA. Av de danska deltagarna, Tor Eriksson och Jingkun Li, är den förstnämnde som fungerat som projektets ledare alltjämt vid Handelshøjskolen vid Århus Universitet medan den sistnämnde numera är verksam vid COWI A/S.

Förutom i denna rapport som huvudsakligen sammanfattar de centrala resultaten och konklusionerna finns den forskning som bedrivits i projektet rapporterad i mera detalj i ett antal vetenskapliga tidskriftsartiklar och i arbetspapper. De centrala forskningsrapporterna i detta avseende är de i litteraturförteckningen nämnda publikationerna av Hakkala, Heyman och 
Sjöholm (2007), Heyman, Sjöholm och Gustafsson Tingvall (2006, 2007) och Eriksson och Li (2006). Såsom så gott som alltid är tillfället i samband med forskningsprojekter kan man nog förvänta sig att ett par ytterligare uppsatser tillkommer senare.

Denna rapport har författats av projektledaren, Tor Eriksson. 


\section{Bakgrund}

Globalisering och internationalisering har blivit något av nyckelord i diskussionen om centrala samhällsfrågor under de senaste åren. Europa befinner sig mitt i en process som syftar till en ytterligare ekonomisk och politisk integration samtidigt som de östasiatiska länderna med Kina i spetsen med hjälp av stark ekonomisk tillväxt blir allt viktigare spelare på världsmarknaderna. De dystra hotbilderna som tecknades för blott ett antal år sedan synes dock ha fått gett vika för en mera nyanserad syn på de utmaningar de utvecklade marknadsekonomierna står inför. Detta kan emellertid till en del också bero på det utomordentligt goda konjunkturläge som kännetecknat ekonomierna i de nordiska länderna; faran för utflyttning av arbetsplatser upplevs givetvis som ett mindre problem i en situation där flera arbetsmarknader de facto präglas av en växande arbetskraftsbrist.

Globalisering är inte enbart en fråga om kraftigt växande handelsvolymer och ökade utlandsinvesteringar, utan innebär även ett intensifierat och fördjupat samarbete mellan länder. Således utgörs de centrala mekanismerna bakom internationaliseringen förutom av rörlighet av varor och tjänster även av växande strömmar av finansiellt kapital och överföring av teknologiska framsteg. Anmärkningsvärt är att arbetskraftsrörligheten inte är en av drivkrafterna av globaliseringen. Med undantag för blott ett litet antal yrkesgrupper kan man inte tala om en global arbetsmarknad. I själva verket är det mot bakgrunden av de enorma löneskillnader som finns mellan länder och världsdelar något av ett mysterium varför den internationella arbetskraftsmobiliteten ligger på en så låg nivå. ${ }^{1}$

Harvard-ekonomen Richard Freeman har träffande beskrivit detta genom att säga att "våra löner inte bestäms i Beijing” (Freeman, 1995). Detta påstående skall dock inte uppfattas bokstavligt. Samma Freeman konstaterar tio år senare (Freeman, 2005) att den enorma ökningen i det globala arbetskraftsutbudet på längre sikt kommer att få betydande följdverkningar på de västliga ekonomiernas arbetsmarknader. Hans bedömning är att utbudet av arbetskraft enbart som en konsekvens av Kinas inträde i WTO ökade med ett antal som motsvarar en tredjedel av OECD:s totala arbetsstyrka. Dessutom har utbudet vuxit ytterligare genom införandet av marknadsekonomi i Indien och öst-Europa (Rysslands eventuella inträde i WTO inte att förglömma). Inom loppet av en förhållandevis kort tidsperiod har således den globala arbetskraften vuxit dra-

\footnotetext{
${ }^{1}$ En central orsak till den låga mobiliteten är de begränsningar på arbetskraftens internationella rörlighet som påförs av ländernas invandringspolitik. Detta betyder i sin tur att en av orsakerna till utflyttning av produktion från de mera utvecklade marknadsekonomerna är den restriktiva invandringspolitik om dessa bedriver. Med lägre hinder för internationell arbetskraftsrörlighet skulle många av de utländska arbetarna i stället flytta till våra länder för att utföra jobben här.
} 
matiskt. Detta innebär fortfarande inte att lönerna - och därmed sysselsättningen - helt och hållet bestäms i en annan del av världen, men lönerna och sysselsättningen i små öppna ekonomier som de nordiska påverkas i allt högre grad än tidigare av vad som sker i andra delar av världen.

\subsection{Internationaliseringens drivkrafter}

En av de centrala drivkrafterna bakom internationaliseringen av arbetsmarknaderna är företagens jakt efter lägre produktionskostnader, och lönekostnader i synnerhet. Men trots att diskussionen ofta kretsar kring löneskillnader mellan länder är kostnadsdifferenserna långt ifrån den enda orsaken till globaliseringen av arbetsmarknaderna. Många företag söker också växande marknader för sina produkter och tjänster och väljer därför att lägga sin produktion närmare dessa. Ett annat centralt motiv för att flytta ut produktion och aktiviteter till andra länder är att man vill öka flexibiliteten - möjligheterna att snabbt reagera på efterfrågeförändringar - och att utöka produktions- och servicekapaciteten utan att för den skull investera i att bygga ut egen produktion och anställa ny personal.

Andra företag är intresserade av speciella former för (typiskt tekniskt) kunnande eller av möjligheter att effektivera sin produktion. Inom högteknologiföretagen är de två sistnämnda målsättningarna med utflyttning avsevärt viktigare än kostnadsbesparingar medan kostnadsreduktioner och ökad flexibilitet anges som viktigare faktorer inom den övriga industrin; se Ali-Yrkkö (2007).

De ovannämnda drivkrafterna har givetvis varit för handen även tidigare och man kan följaktligen fråga sig varför internationaliseringen verkar att vara speciellt påtaglig just nu. En orsak är utan tvivel de nya informations- och kommunikationsteknologiska vinningarna som skapar klart bättre förutsättningar för mobilitet inom och mellan länder. Därtill kommer den samtidiga utvidgningen av EU, slutet på det kalla kriget, Kinas inträde i WTO - faktorer som kommit i stort sett samtidigt och alla har bidragit till avsevärt större öppenhet och kraftigt ökad handel mellan länder.

Tabell 1. Direkta utlandsinvesteringar (bestånd i procent av BNP) från och till de nordiska länderna, 1990 och 2002

\begin{tabular}{llcc}
\hline Land & Från/till & 1990 & 2002 \\
\hline Danmark & Från & 5,5 & 43,4 \\
& Till & 6,9 & 41,7 \\
Finland & Från & 8,2 & 52,8 \\
& Till & 3,8 & 27,0 \\
Sverige & Från & 21,3 & 60,5 \\
& Till & 5,3 & 46,0 \\
\hline
\end{tabular}

Källa: UNCTAD 
Hur som helst har de senaste två årtiondena inneburit markanta förändringar i den internationella handeln. Denna har vuxit mycket starkt som en följd av liberaliseringen och avregleringen på det handelspolitiska området men också i viss mån som en konsekvens av framstegen på transport- och kommunikationsområdet vilka väsentligt minskat de geografiska avståndens betydelse. Samtidigt har de internationella direktinvesteringarnas betydelse ökat kraftigt. Enligt beräkningar från UNCTAD har den totala volymen av utländska direktinvesteringar sexfaldigats sedan början 1990-talet. Denna tillväxt överstiger klart tillväxten i den totala globala exporten och världs-BNP. ${ }^{2}$ Tillväxten i utländska direktinvesteringar var i synnerhet snabb under nittiotalet till följd av den ökade handeln med de tidigare kommunistiska länderna i Central- och ÖstEuropa, den gemensamma marknaden i EU, den nordamerikanska integrationen (NAFTA) och guldrushen till Kina. Tillväxten har under de senaste åren stannat upp något, men ligger alltjämt på en högre nivå än perioden innan nittiotalet.

Det ovansagda gäller också för de nordiska länderna; se Tabell 1. I Danmark har direktinvesteringarnas (såväl till som från landet) andel av BNP sex- till sjufaldigats under denna period. Utvecklingen i Finland och Sverige avviker något från den danska till den grad att utflödet av direktinvesteringar har varit större än inflödet. Mätt i andelar av BNP ligger de utländska direktinvesteringarna i Finland på en lägre nivå än i Danmark och Sverige. I Sverige har företagens direktinvesteringar i utlandet redan tidigare legat på en högre nivå (även internationellt sett på en hög nivå som i Europa enbart finns i Storbritannien och Nederländerna) och gör det alltjämt.

Hittills har effekterna av den växande integrationen varit mest påtagliga inom industrin. Sålunda hade enligt en intervju-undersökning som företogs i Danmark år 2005, 85 procent av de danska företag som hade företagit någon form av outsourcing under de föregående åren, flyttat ut produktion av fysiska varor (dvs. industriprodukter) medan 12 procent hade flyttat ut sina informationsteknologiska aktiviteter (Dansk Industri, 2003). Utflyttningen är alltså synnerligen koncentrerad till industrisektorn. I en liknande intervju-undersökning som företogs av ETLA år 2006 (Ali-Yrkkö (2006)) och som riktade sig till ett representativt urval av i Finland verksamma företag med flera än tio anställda, finner man ett liknande mönster; se Tabell 2. ${ }^{3}$ Andelen företag som flyttat ut produktion utanför landets gränser är lägre i Finland än i Danmark och Sverige. Däremot visar Ali-Yrkkö (2007) att utflyttning av forsknings- och utvecklingsaktiviteter är tämligen vanligt förekommande - till och med överraskande frekvent - i de finska industri-

\footnotetext{
${ }^{2}$ Tillväxten i de två sistnämnda har legat på ungefär samma nivå som under 1960-talet, en annan högväxtperiod i modern tid.

${ }^{3}$ Undersökningen är synnerligen intressant i så måtto att den först frågar företagen om de har flyttat ut aktiviteter och sedan om utflyttningen skett till andra företag inom landet eller till utlandet. Den förstnämnda andelen är avsevärt större än den senare. Sålunda anger ca 2/3 av företagen inom tillverkningsindustrin att de har flyttat ut delar av sin produktion till ett annat (eller andra) företag i Finland.
} 
företagen, och i högteknologiföretagen i synnerhet. Ali-Yrkkö (2006) redovisar beräkningar enligt vilka utlandspersonalen i finländska industriföretag vuxit med något flera än 60000 personer under det första årtiondet av detta sekel. Av denna ökning härrör 80-85 procent ur faktisk expansion av produktionen i utlandet, uppköp av utländska företag eller nyetableringar och är följaktligen i mindre grad en konsekvens av utflyttning av aktiviteter från Finland till utlandet.

Tabell 2. Utflyttning av olika funktioner inom den finska industrin (\% av antalet företag)

\begin{tabular}{lcccccc}
\hline & \multicolumn{2}{c}{ Flyttat ut (\%) } & \multicolumn{2}{c}{ Flyttat ut i Finland (\%) } & \multicolumn{2}{c}{ Flyttat ut till utlandet (\%) } \\
& $\begin{array}{l}\text { Högtek- } \\
\text { nologi } \\
\text { Industri }\end{array}$ & $\begin{array}{c}\text { Annan } \\
\text { industri }\end{array}$ & $\begin{array}{c}\text { Högtek- } \\
\text { nologi } \\
\text { industri }\end{array}$ & $\begin{array}{c}\text { Annan } \\
\text { industri }\end{array}$ & $\begin{array}{r}\text { Högtek- } \\
\text { nologi } \\
\text { industri }\end{array}$ & $\begin{array}{c}\text { Annan } \\
\text { industri }\end{array}$ \\
\hline Tillverkning & $33,7 \%$ & $31,0 \%$ & $31,7 \%$ & $30,0 \%$ & $20,1 \%$ & $5,4 \%$ \\
FoU & $32,2 \%$ & $23,0 \%$ & $32,0 \%$ & $22,3 \%$ & $10,3 \%$ & $7,4 \%$ \\
Servicefunktioner & $50,9 \%$ & $54,6 \%$ & $50,9 \%$ & $51,5 \%$ & $1,1 \%$ & $3,9 \%$ \\
\hline
\end{tabular}

Källa: Ali-Yrkkö (2007)

\subsection{Servicenäringarna, nästa?}

Såsom utvecklingen under de senaste åren tydligt har visat, möjliggör de nya informations- och kommunikationsteknologierna även en flyttning av flera av företagens servicetjänster till andra länder. Ett antal ekonomer se t.ex. Baghwati m.fl. (2005) - har dock hävdat att endast en relativt liten del av tjänstesektorns aktiviteter sannolikt kommer att utflyttas eftersom många transaktioner typiskt förutsätter att såväl säljaren som köparen befinner sig fysiskt på samma plats eller att köparens modersmål är avgörande för lokaliseringen av köpplatsen.

Denna uppfattning är rätt allmän men har emellertid allt oftare ifrågasatts; se t.ex. Amiti och Wei (2005) som varnar för att dra allt för långt gående slutsatser på basen av ett fåtal observationer. Alan Blinders (2006) bedömning är att t.o.m. så många som hälften av alla jobb i servicesektorn i USA är av en sådan karaktär att de inte kräver en face-to-face kontakt mellan säljare och köpare och att en elektronisk transmission av de involverade uppgifterna kan utföras utan nämnvärda försämringar i transaktionens kvalitet. I en nyare uppsats har Blinder (2007) gjort ett försök att rangordna 800 jobbtitlar (enligt Bureau of Labor Statistics klassificeringssytem) enligt graden av utflyttbarhet ("offshorability"). Hans slutsats är att mellan 22 och 29 av alla jobb kunde utflyttats i loppet av ett årtionde eller två. Graden av utflyttbarhet bestäms av behovet av face-toface kontakt, fysisk närhet till arbetsplatsen, närhet till natur- andra resurser, m.m. Ett yrkes utflyttbarhetsgrad är blott svagt korrelerad med utbildningskrav för att utföra jobbet och den nuvarande (median)lönen för det samma. 
I ett annat försök att kvantifiera det potentiella antalet servicejobb som kan flyttas ut utnyttjar Jensen och Kletzer (2005) sig av information om den geografiska koncentrationen av service-aktiviteterna i USA för att identifiera tjänster som uteslutande kan handlas inom landet. Det kritiska antagandet i deras analys är att de för närvarande inhemskt handlade tjänsterna (som är geografiskt koncentrerade till vissa områden) inte kan bli föremål för internationell handel. Denna beräkningsmetod förser oss med en uppskattning av andelen sysselsatta inom tjänstenäringarna som potentiellt kan utflyttas till omkring 39 procent.

Det är viktigt att hålla i minnet att industrisektorn i de utvecklade kapitalistiska samhällena står för blott cirka 15 procent av BNP och att den redan under en längre tid varit utsatt för en betydande internationell konkurrens. En ytterligare koncentration av industriarbetsplatser till öst-Asien påverkar därför inte industrisektorn i de nordiska ländernas i tillnärmelsevis lika stor utsträckning som i Latin-Amerika, Ryssland, Afrika och i asiatiska länder med högre löner såsom Taiwan, Hong Kong, Syd-Korea och Japan. I dessa länder är industrin satt under betydligt starkare press.

I vår del av världen är det på längre sikt mera intressant att fästa blicken på servicesektorn. Såsom vi såg ovan kan nämligen den internationella integrationens effekter på arbetsmarknaderna mycket väl sprida sig utanför industrisektorn. Det viktigt att notera att lokaliseringen av industriproduktionen i stor utsträckning beror på att företagen har tillgång till viktiga naturresurser, vilket lägger vissa restriktioner på möjligheterna att flytta produktionen. De komparativa fördelarna inom tjänstesektorn, och den nya ekonomin i synnerhet, återspeglar däremot i en avsevärt högre grad människors idéer, beslut och ansträngningar. Av denna orsak finns det mindre trögheter i denna sektor vilket i sin tur innebär att den är mindre förutsägbar också vad gäller dess lokalisering. Det är dessutom viktigt att notera att när jobben flyttas ut från servicesektorn är det till skillnad från industrin inte enbart lågkvalificerad arbetskraft som drabbas. Exempel på kvalificerade jobb som flyttas ut i den senaste tiden är dataprogrammering, radiologi och bokföring. Dessa är inte bara relativt kvalificerade arbetsuppgifter men även exempel på jobb som utförs av personer som sannolikt kan organisera ett starkare motstånd mot dessa förändringar än vad den lågkvalificerade arbetskraften inom industrin hittills har bjudit på.

\subsection{Internationalisering också på hemmaplan}

De förhållandevis stora och snabba förändringarna i den geografiska lokaliseringen av världens industriproduktion och i det internationella mönstret i direkta utlandsinvesteringar har naturligtvis skapat en intensiv debatt om konsekvenserna av dessa ändringar liksom även ökade forskningssatsningar för att informera denna diskussion. Intressant nog har 
betydligt mindre uppmärksamhet ägnats åt det faktum att internationaliseringen inte är en enkelriktad gata: som en följd av liberaliseringen av finansmarknaderna, den fortsatta och fördjupade europeiska integrationen och den fortgående avregleringen av utrikeshandeln har de utvecklade marknadsekonomierna också internationaliserats till följd av att en växande andel av företagen i dem har fått utländska ägare.

En OECD-studie från 2003, rapporterad i Golub (2003), har konstruerat indexar för regleringen av utländskt ägande i OECD-länderna. Indexvärden, vilka baserar sig på indikatorer som mäter begränsningar i utlänningars aktieinnehav i enskilda företag, procedurer för att godkänna utländska ägare samt andra restriktioner, t.ex. rörande sammansättningen av företagets styrelse, har beräknats för åren 1980, 1990 och 2000 ${ }^{4}$. Analysen dokumenterar mycket tydligt omfattningen av den avreglering som skett på området, i synnerhet i Europa ${ }^{5}$. År 1980 hörde Finland, Norge och Island (tillsammans med Turkiet och Portugal) till de mest restriktiva länderna inom OECD beträffande utländska direktinvesteringar och Sverige var något, men inte mycket, mindre reglerat. Däremot hörde Danmark till de mera liberala länderna (och överträffades enbart av England, Tyskland och USA). Avregleringen vilken inträffade i samtliga nordiska länder under nittiotalet har lett till att de i början av detta århundrade, med undantag för Island (som alltjämt är det mest reglerade landet inom OECD), ligger nära OECD-genomsnittet.

Tabell 3. Index för begränsningar för utländska direktinvesteringar i de nordiska länderna 1980, 1990 och 2000

\begin{tabular}{lrrr}
\hline & 1980 & 1990 & 2000 \\
\hline Danmark & 0,246 & 0,161 & 0,087 \\
Finland & 0,521 & 0,463 & 0,177 \\
Island & 0,600 & 0,481 & 0,390 \\
Norge & 0,510 & 0,466 & 0,182 \\
Sverige & 0,429 & 0,335 & 0,140 \\
\hline
\end{tabular}

Källa: Golub (2003)

Mot denna bakgrund är det inte överraskande att andelen utlandsägda företag även har vuxit i de nordiska länderna. Cirka 20 procent av de anställda inom den privata sektorn i Danmark och Sverige arbetar i utlandsägda företag ${ }^{6}$ och i Finland har antalet utlandsägda företag mera än trefaldigats sedan början av nittiotalet. Enligt ITPS (2006) har andelen av hela arbetskraften som är sysselsatta i utlandsägda företag i Sverige vuxit

\footnotetext{
${ }^{4}$ Indexvärdena ligger i intervallet 0 till 1 och ett högre värde anger ett större antal och mera genomgripande begränsningar för utlandsinvesteringar. De högsta och lägsta värdena noteras för Island år 1980 $(0,600)$ respektive Irland år 2000 (0,074).

${ }^{5}$ Utvecklingen i de icke-europeiska OECD-länderna har varit betydligt långsammare. Sålunda låg indexvärdet för t.ex. USA klart under OECD-genomsnittet i 1980, medan värdena för år 2000 sammanfaller.

${ }^{6}$ Ett företag definieras som utlandsägt om mer än hälften av aktierna i företaget är i utländska händer. Se även fotnot 7 .
} 
från 9 procent i 1990 till 23 procent år 2006. Bakom dessa tal döljer sig rätt stora skillnader mellan industrin och tjänstesektorerna. I den förstnämnda har andelen sysselsatta i utlandsägda företag vuxit från 14 till 34 procent och inom tjänstesektorn från 6 till 20 procent. Dessa andelar är anmärkningsvärt stora även i en internationell jämförelse. Således ligger Sverige i en OECD-undersökning från 2002 i toppen vid sidan av Irland och Luxemburg vad gäller utlandsägandet inom bägge sektorerna (OECD, 2002). De andra nordiska länderna intar klart blygsammare positioner $^{7}$ men fortsätter utvecklingen som hittills kommer de framgent att klättra flera pinnhål i rangordningen.

I Finland har andelen sysselsatta i utlandsägda företag vuxit från 9 procent år 1994 till 18 procent år 2002. Tillväxten i andelen sysselsatta i de utlandsägda företagen har varit speciellt snabb inom industrin. Sålunda har andelen där vuxit från 5 procent år 1991 till 23 procent tio år senare (Huttunen, 2007). Men även inom tjänstesektorn ligger andelen på 12 procent år 2002 (OECD, 2003). Den ovannämnda OECD-rankingen baserar sig för Danmarks del på gamla missvisande uppgifter ${ }^{8}$ och underskattar kraftigt andelarna liksom även landets position i rangordningen. För Norge har vi enbart uppgifter från 2002 och de ger vid handen att andelen anställda i utlandsägda industriföretag var 22 procent medan andelen inom servicesektorn låg på futtiga 3 procent. För alla de tre här studerade länderna gäller att det ökade utlandsägandet huvudsakligen skett genom utländska uppköp av redan existerande (inhemska) företag och i avsevärt mindre utsträckning genom nyetableringar.

En naturlig fråga att ställa sig är: kan dessa ändringar i ägandestrukturen äga rum utan att de påverkar de nordiska arbetsmarknaderna och i synnerhet sysselsättnings- och lönestrukturerna? Det vänder vi tillbaka till i kapitel 6.

\footnotetext{
${ }^{7}$ Balsvik och Haller (2006) anger att andelen anställda i utlandsägda företag inom den norska industrisektorn har vuxit från 9 procent i 1990 till 16 procent tio år senare. Det är värt att notera att dessa tal, liksom de som finns i huvudtexten ovan, anger andelen anställda i företag som är i direkt utländsk ägo. Om företag som indirekt ägs av utländska i Norge verksamma moderföretag även inkluderas, stiger de ovannämnda andelarna till 13 respektive 38 procent - en anmärkningsvärt stor ökning.

${ }^{8}$ Denna missvisande statistik som rättades till av Danmarks Statistik så sent som år 2005 har också utgjort ett stort problem i det danska delen av det aktuella projektet och i hög grad bidragit till att dess slutförande försenats.
} 



\section{Mycket kort om vad ekonomisk teori säger}

Det är på sin plats att inledningsvis konstatera att de flesta ekonomiska analyser av utflyttning har fokuserat på företagens beslut om produktionens lokalisering och om hur företaget skall organisera sina aktiviteter; för en typisk teori-översikt, se Spencer (2005). Det finns avsevärt mindre analyser av utflyttningarnas välfärdseffekter. Detta återspeglar många ekonomers syn på utflyttning som blott en ny form av internationell handel. Liksom lekmän, och politiker i synnerhet, inser även ekonomer att ökad handel nog skapar vinnare och förlorare men till skillnad från lekmännen poängterar de att den också skapar ökad välfärd som en följd av högre produktivitet och större inkomster totalt sett. Argumenten för frihandel är dock rätt subtila och kan inte sammanfattas på en dekal som får plats en normal personbils bakruta.

Även om det är vanligt att föreställa sig att ökad konkurrens från låglöneländer innebär en högre risk för att den lågt utbildade och kvalificerade arbetskraften förlorar sina jobb, förser standard ekonomisk teori oss inte med så klara besked. I själva verket ger traditionella statiska allmänjämviktsmodeller för handel mellan länder inte entydiga prediktioner i detta avseende. Detta beror på att den billigare produktionen ökar konsumenternas realinkomster vilket i sin tur leder till att efterfrågan på andra varor och tjänster ökar ${ }^{9}$. Här är det viktigt att notera att den konventionella utrikeshandelsteorin avser handel med slutprodukter medan modern utrikeshandel innehåller ett betydande inslag av handel av uppgifter och intermediära produkter (dvs. varor och tjänster som används som insatsfaktorer i produktionen av de slutliga varorna). Detta gäller för såväl industriprodukter som tjänster. Handeln med uppgifter reflekterar den fragmentering av företagens värdekedjor som litteraturen om företagens organisation har fokuserat på.

Under de senaste åren har ett antal ekonomer börjat bygga modeller som fångar upp utvecklingen mot en växande handel med intermediära varor och uppgifter. En central fråga är hur fragmenteringen påverkar

\footnotetext{
${ }^{9}$ Teorin för multinationella företag skiljer mellan fyra olika effekter av ökade direktinvesteringar i utlandet på moderföretaget. Den första är att den utländska investeringen undantränger produktion och sysselsättning i moderföretaget. En annan är att exporten stimuleras vilket i sin tur bidrar till att öka antalet nya arbetstillfällen inom företaget (i moder - och i dotterföretaget). En tredje effekt är att ökad produktion i de utländska dotterföretagen leder till ökad sysselsättning i moderföretaget i form av jobb som utförs där, t.ex. lednings- och koordineringsuppgifter eller forsknings- och utvecklingsuppdrag. En fjärde effekt består i ett förändrat antal personer sysselsatta i olika stödfunktioner såsom bokföring, marknadsföring, konsulttjänster, m.m. Var dessa nya jobb uppkommer beror naturligtvis på om stödfunktionernas lokaliseras nära den nya produktionen eller ej.
} 
handeln, länders välfärd och priser på insatsfaktorer (inklusive löner). Till skillnad från traditionell teori i vilken företagens beslut är av marginell natur (mer eller mindre) är de i de nya modellerna av diskret karaktär (utföra uppgiften själv eller köpa den från marknaden/utlandet) vilket gör analysen något mera komplicerad. Det innebär också att det är svårare att nå fram till generella entydiga prediktioner. Trots att det på sistone har gjorts framsteg i detta hänseende är den teoretiska litteraturen om de nya handelsformerna rätt ung och mycket arbete återstår. 


\section{Att beskriva och mäta globalisering och utflyttning}

Trots att diskussionen om globalisering och utflyttning av produktion har varit livlig i flera års tid är det rätt tunnsått med faktaunderlag för att informera debatten. Denna präglas i stor utsträckning av enstaka händelser, anekdotisk evidens och grova generaliseringar. Avsaknaden av data som beskriver fenomenet innebär naturligtvis att empirisk forskning som belyser det är ganska ovanlig.

\subsection{Direkta mått}

Konventionell, av statistiska centralbyråer producerad, statistik, liksom källorna till denna, är med undantag för handelsstatistiken inte internationell. Sålunda beskriver produktions- och syssel-sättningsstatistiken uteslutande vad företag och organisation gör inom ett lands gränser. Internationella statistiska organisationer som Eurostat samlar i mycket begränsad utsträckning in egen statistikinformation, utan förlitar sig i stället i mycket hög grad på medlemsländernas nationella statistiker. Det vore dock orättvist att i detta sammanhang inte nämna OECD:s omfattande utvecklingsarbete för att skapa indikatorer för globaliseringen. Detta arbete har också resulterat i ny, värdefull statistik som regelbundet publiceras av OECD. Det oaktat är situationen långt ifrån tillfredställande och forskningen kring liksom även bevakningen av internationaliseringen av företag och företagens utflyttningsaktiviteter kan inte baseras på existerande konventionella datakällor.

I USA har Bureau of Labor Statistics (BLS) vid arbetsministeriet sedan 2004 som ett led i sitt Mass Layoffs Statistics program börjat registrera antalet arbetsplatser som försvinner till följd av utflyttad produktion ${ }^{10}$. BLS använder sig av en ofta utnyttjad metod för att mäta omfattningen av ändringarna, kallad media tracking, och som går ut på att man hämtar information från media, typiskt dagstidningar. Även EU:s European Restructuring Monitor Programme använder sig av denna metod. Den är dock inte helt oproblematisk eftersom den kan påverkas av i vilken grad ett fenomen upplevs som nytt av media. Sålunda exploderade t.ex. intresset för outsourcing i amerikanska media under den föregående

\footnotetext{
${ }^{10}$ USA hör till de få länder som regelbundet samlar in information om de (amerikanska) multinationella företagens aktiviteter i utlandet. Detta arbete utförs vid Bureau of Economic Analysis och förser beslutsfattare och andra med information om de multinationella företagens inkomster, investeringar, export och import samt löner och sysselsättning såväl i hemlandet som i dotterföretagen i utlandet.
} 
presidentvalskampanjens sista halvårsperiod (februari till oktober 2004) för att sedan igen återgå till normala nivåer. Vidare finns det belägg från USA för att företagen försöker dölja information om utflyttningar på grund av den dåliga publicitet som är förknippad med dem.

\subsection{Indirekta mått}

De flesta empiriska studier av konsekvenserna av internationaliseringen av företagen och av företagens utflyttningsaktiviteter har följaktligen tvingats använda sig olika surrogatmått på utflyttning av produktion eller delar av densamma. Dessa hämtas vanligen från handelsstatistiken. Ett ofta utnyttjat mått, som ursprungligen föreslagits av Feenstra och Hanson (1996), (1999), är värdet av importerade intermediära produkter. Idéen är här att fånga upp fragmenteringen av produktionsprocesserna, dvs. alla de situationer där företaget upphör att producera en mellanprodukt eller tjänst själv och i stället köper den från en utländsk producent. Handeln med mellanprodukter har vuxit kraftigt under de två senaste årtiondena; beräkningar baserade på handelsdata från tio OECD-länder under nittiotalet gav vid handen att ungefär 30 procent av dessa länders samlade export utgjordes av intermediära produkter (Hummels m.fl., 2001) ${ }^{11}$. Således är det inte utan intresse att få att veta hur dessa förändringar har påverkat arbetskraftsefterfrågan i de berörda företagen.

Två svagheter vidlåder emellertid denna typ av analyser. För det första fångar måttet intet upp utflyttning av produktion av slutliga varor och tjänster. "Mannen på gatan” uppfattar begreppen utflyttning, outsourcing eller offshoring som utflyttning av ett helt företag eller en hel produktionsenhet eller åtminstone ett större antal arbetstillfällen till ett låglöneland, och tänker nog inte först och främst på fragmenteringen av produktionen som en del av dessa. Ett problem är således att användingen av värdet av importerade intermediära produkter tenderar att underskatta omfattningen av globaliseringen av produktionen.

För det andra konstrueras måttet vanligtvis från nationalräkenskapernas input-output-tabeller och är därför i de flesta länder endast tillgängliga på branschnivå. Att genomföra analysen på branschnivå är dock problematiskt. Vi är til syvende og sidst intresserade av företagens beteende och vi vet från annan forskning att företag - även inom snävt definierade branscher - avviker avsevärt från varandra. Det finns ingen anledning att tro att detta inte även är fallet för utflyttning av produktion eller uppgifter. Den empiriska evidensen tyder faktiskt på motsatsen. Ytterligare ett problem är att när man aggregrar upp data till branschnivån så kan man inte skilja mellan ändringar på den extensiva och den intensiva margina-

\footnotetext{
${ }^{11}$ Ett annat centralt utvecklingsdrag i den växande handeln är att ekonomierna blir mera specialiserade genom att handeln inom (i motsats till handeln mellan) branscher vuxit i betydelse, övervägande som en följd av produktdifferentiering och stordriftsfördelar.
} 
len. Med andra ord kan man inte särskilja mellan ändringar som beror på att ett företag upphör att existera/ett nytt företag föds eller på att ändringar i storleken på existerande företag äger rum. Allt som allt betyder detta att analyser som utnyttjar variabler som beskriver utflyttning på en högre aggregeringsnivå än företaget kan vara synnerligen missvisande.

När vi har sagt detta, skall man emellertid också vara uppmärksam på att även analyser som fokuserar på företaget som analysenhet är behäftade med vissa svagheter. Observera att nu talar vi om den beroende variabeln i den statistiska analysen, som kan vara t.ex. sysselsättningen eller genomsnittslönen i företaget. Flera av de tidigaste studierna på området undersökte hur de multinationella företagens utlandsinvesteringar påverkade sysselsättningen i moderföretaget i hemlandet. En del av de nyare undersökningarna studerar också multinationella företag. En begränsning hos dessa studier är att eftersom de tar utgångspunkt i ett urval av företag som är multinationella redan i början av den studerade perioden, säger de ingenting om effekterna av ett företags första utflyttnings- eller utlandsinvesteringsbeslut. Vi kan förvänta oss att denna begränsning är speciellt allvarlig för perioder - t.ex. de senaste tio åren - då utflyttning eller direkta utlandsinvesteringar sprider sig bland betydligt flera företag än tidigare.

Men även om urvalet består av andra än multinationella företag finns det ytterligare en begränsning som är värd att understryka i synnerhet om man önskar använda sig av forskningsresultaten för att informera politiska beslutsfattare. Ur ett policyperspektiv är det nämligen inte effekten av direkta utlandsinvesteringar eller utflyttning av produktion och uppgifter på företagets sysselsättning (eller lön) man primärt är intresserad av att få en skattning av, utan hur dessa påverkar den lokala arbetsmarknaden (eller regionen) företaget befinner sig på. En utflyttning av en del av produktionen till ett låglöneland kan nämligen komma att inte enbart påverka sysselsättningen i hemmaföretaget, utan även hos dess underleverantörer. Notera att den sistnämnda effekten inte behöver vara negativ ${ }^{12}$. Hur som helst illustrerar detta resonemang att en beroende variabel på företagsnivå inte fångar upp de externaliteter och spillover-effekter till andra företag som kan vara förknippade med en utflyttning eller en utlandsinvestering. Dessa effekter kan vara betydande. Analyser på branschnivå fångar emellertid inte heller upp dem eftersom spillover-effekterna oftast inte stannar inom branschen, men står att finna i regionen eller på den lokala arbetsmarknaden ${ }^{13}$.

Summa summarum, saknas det i många avseenden bra statistik för att beskriva och bevaka internationaliseringen av våra företag och arbetsmarknader. Detta betyder naturligvis att även forskningen kring dessa frågor allvarligt begränsas av bristen på relevant statistisk information.

\footnotetext{
${ }^{12}$ En utflyttning av produktion kan ju också innebära att den lokala underleverantören upplever en ökad efterfrågan på de intermediära produkterna.

${ }^{13}$ Se dock Amiti och Wei (2005) som visar att utflyttning av servicejobs tenderar att motverkas av att nya jobb skapas inom samma sektor. Detta är även förenligt med att länder vars företag i betydande grad flyttat ut servicejobb - såsom t.ex. England och USA som kan göra detta i högre grad tack vare det engelska språket - samtidigt har ett överskott i betalaningsbalansen för handeln med tjänster.
} 



\section{Utflyttningens konsekvenser - tidigare forskning}

\subsection{Studier på branschnivå}

En stor del av den internationella forskningen om internationaliseringens arbetsmarknadskonsekvenser kommer från USA. Detta är måhända något förvånande mot bakgrunden av att den amerikanska ekonomin är långt mera sluten, dvs. berörs i mindre utsträckning av utrikeshandel, än de flesta europeiska länders ekonomier. En betydande del av dessa studier använder sig av mått som beskriver internationaliseringen på branschnivå; en översikt av denna litteratur ges i Feenstra och Hanson (2003). Många av undersökningarna ger vid handen att en ökad internationalisering leder till en förskjutning av arbetskraftsefterfrågan från okvalificerad mot mera kvalificerad arbetskraft. Vidare sjunker den okvalificerade arbetskraftens relativlöner. Med andra ord drabbas arbetare med bristande kvalifikationer i form av en minskning av antalet arbetsplatser och de som behåller sina arbetsplatser upplever lönesänkningar relativt andra arbetstagargrupper.

I Tabell 4 nedan sammanfattas de empiriska studierna från andra länder än USA fr.o.m. nittiotalets början. Ett antal liknande undersökningar har nämligen även utförts för de större EU-länderna Storbritannien, Frankrike och Tyskland; se Hijzen m.fl. (2005), Strauss-Kahn (2003) respektive Falk och Kobel (2002). Intressant nog finner de liknande effekter som i de amerikanska studierna. Resultaten för England är möjligen mindre överraskande eftersom arbetsmarknaden där, liksom den amerikanska, kännetecknas av en betydande löneflexibilitet och av att arbetskraftsefterfrågan inom den brittiska industrin har sjunkit kraftigt. Frankrike och Tyskland är däremot mera intressanta fall. Till skillnad från de flesta andra västeuropeiska länder har Tyskland under såväl åttio- som nittiotalet haft en mycket stabil löne- och inkomstfördelning. Det är därför anmärkningsvärt att en undersökning som utnyttjar data helt ned på individnivå (Geishecker och Görg, 2008) finner att utflyttningen av produktion till andra länder har medfört en minskning i de minst kvalificaerde medarbetarnas relativlöner saamtidigt som den kvalificerade arbetskraften i de berörda företagen njutit av en god förtjänstutveckling. Frankrike har av tradition haft en synnerligen reglerad arbetsmarknad och hör även till de europeiska länder där befolkningen enligt Eurobarometers undersökning från år 2003 har den mest negativa inställningen till globaliseringstendenserna. Strauss-Kahn (2003) visar att en icke oväsentlig del (cirka 20 procent) av den negativa sysselsättningsutvecklingen för den 
okvalificerade arbetskraften inom industrin kan tillskrivas utflyttning av produktion till andra länder.

Tabell 4. Studier av effekterna av internationell utflyttning på arbetskraftsefterfrågan. Utflyttning på branschnivå

\begin{tabular}{|c|c|c|c|c|c|}
\hline Undersökning & Land & $\begin{array}{l}\text { Den totala syssel- } \\
\text { sättningen }\end{array}$ & $\begin{array}{l}\text { Kvalificerad } r \\
\text { okvaliferad } \\
\text { arbetskraft }\end{array}$ & resp. & Annat \\
\hline $\begin{array}{l}\text { Hijzen } \\
(2005)\end{array} \quad$ m.fl. & Storbritannien & & $\begin{array}{l}\text { Efterfrågan } \\
\text { okvalificerad } \\
\text { arbetskraft } \\
\text { sjunker }\end{array}$ & på & \\
\hline $\begin{array}{l}\text { Strauss-Kahn } \\
(2002)\end{array}$ & Frankrike & & $\begin{array}{l}\text { Efterfrågan } \\
\text { okvalificerad } \\
\text { arbetskraft } \\
\text { sjunker }\end{array}$ & på & \\
\hline $\begin{array}{l}\text { Falk och Kobel } \\
(2002)\end{array}$ & Tyskland & & $\begin{array}{l}\text { Efterfrågan } \\
\text { okvalificerad } \\
\text { arbetskraft } \\
\text { sjunker }\end{array}$ & på & \\
\hline $\begin{array}{l}\text { Geishecker och } \\
\text { Görg (2004) }\end{array}$ & Tyskland & & & & $\begin{array}{l}\text { Den okvalificera- } \\
\text { de arbetskraftens } \\
\text { relativlön sjunker }\end{array}$ \\
\hline Hansson (2005) & Sverige & $\begin{array}{l}\text { Efterfrågan på } \\
\text { produktionsarbe- } \\
\text { tare faller }\end{array}$ & & & $\begin{array}{l}\text { Vid utflyttning } \\
\text { utanför OECD }\end{array}$ \\
\hline $\begin{array}{l}\text { Ekholm och } \\
\text { Hakkala (2006) }\end{array}$ & Sverige & & $\begin{array}{l}\text { Efterfrågan } \\
\text { okvalificerad } \\
\text { arbetskraft } \\
\text { sjunker }\end{array}$ & på & $\begin{array}{l}\text { Utflyttning till } \\
\text { Central- och öst- } \\
\text { Europa }\end{array}$ \\
\hline $\begin{array}{l}\text { Sørensen och } \\
\text { Skaksen (2005) }\end{array}$ & Danmark & $\begin{array}{lr}\text { Efterfrågan ökar } \\
\text { inom IT, elektro- } \\
\text { nik och kemisk } \\
\text { industri. } & \text { Minskar } \\
\text { inom } & \text { textil- } \\
\text { industrin } & \end{array}$ & & & \\
\hline $\begin{array}{l}\text { Rosholm m.fl. } \\
(2007)\end{array}$ & Danmark & & $\begin{array}{l}\text { Efterfrågan } \\
\text { okvalificerad } \\
\text { arbetskraft } \\
\text { sjun- } \\
\text { ker/kvalificera } \\
\text { växer }\end{array}$ & $\begin{array}{l}\text { på } \\
\text { ad }\end{array}$ & $\begin{array}{l}\text { Utflyttning till } \\
\text { låg/höglöneländer }\end{array}$ \\
\hline $\begin{array}{l}\text { Hsie och Woo } \\
(2005)\end{array}$ & Japan & $\begin{array}{l}\text { Stor negativ } \\
\text { effekt på efter- } \\
\text { frågan på pro- } \\
\text { duktionsarbetare }\end{array}$ & & & \\
\hline $\begin{array}{l}\text { Head och Ries } \\
(2002)\end{array}$ & Hong Kong & $\begin{array}{l}\text { Stor negativ } \\
\text { effekt på efter- } \\
\text { frågan på pro- } \\
\text { duktionsarbetare }\end{array}$ & & & \\
\hline
\end{tabular}

Liknande studier för Sverige finner att utflyttning av produktion till länder utanför OECD-området har negativa effekter på sysselsättningen för produktionsarbetare inom industrin (Hansson, 2005) samt att ökade uppköp av intermediära produkter från låglöneländer, och central- och östEuropa i synnerhet, har negativa effekter på arbetskraft med mellanstadieutbildning (Ekholm och Hakkala, 2006). Motsvarande analyser för Danmark ger en något mera blandad bild (Sørensen och Skaksen, 2005). 
Sysselsättningskonsekvenserna är föga överraskande negativa inom textilindustrin, men positiva inom t.ex. kemisk industri, IT- och elekronikbranscherna. En nyare pågående studie av sysselsättningseffekterna inom dansk industri och som utnyttjar branschnivådata för outsourcingvariabeln men skiljer mellan olika länder (Rosholm, Scheuer och Sørensen, 2007) finner att internationell utflyttning och importpenetration från låglöneländer leder till en minskad efterfrågan på okvalificerad arbetskraft medan ökad import från höglöneländer har en motsatt effekt. För Finland och Norge finns inte studier som belyser effekterna av utflyttning på sysselsättningen.

En handfull studier från Hong Kong (Hsie och Woo, 2005), Taiwan (Yeh och Lin, 2006) och Japan (Head och Ries, 2002) visar på avsevärt större negativa sysselsättningseffekter av utflyttning av produktion till grannländerna, framför allt Kina, än de vi finner i de amerikanska och europeiska studierna. Andelen produktionsarbetare inom industrin i Hong Kong föll från år 1976 till 1996 från 88 till 52 procent. Hälften av detta dramatiska fall kan enligt Hsie och Woos (2005) studie tillskrivas utflyttningen av produktion och uppgifter till Folkrepubliken. Vi känner inte till motsvarande studier för Mexiko, det övriga Latin-Amerika eller Ryssland och de forna asiatiska sovjetrepublikerna. En plausibel hypotes är dock att industrisysselsättningen i många av dessa länder har påverkats mera än de europeiska eller de nordiska länderna.

\subsection{Studier på företagsnivå}

Som tidigare nämndes baserar sig färre studier på information på företagsnivå. Och ändå är denna litteratur faktiskt äldre och går tillbaka till ett antal undersökningar av hur en expansion av multinationella företags aktiviteter i utlandet påverkar hemmaföretaget ${ }^{14}$. Denna diskussion fördes i USA i slutet av sjuttiotalet och en bit in på åttiotalet och förekom i viss omfattning också i Sverige; se Swedenborg (1979). De tidigaste studierna från sjuttio- och åttiotalen fann i regel att en ökning i aktiviteterna i utlandet medförde en ökad sysselsättning i moderföretaget i hemlandet. Tabell 5 innehåller en kort beskrivning av de nyare empiriska analyserna som baserats på data i vilka utflyttningen mäts på företagsnivå.

Nyare undersökningar som t.ex. Blomström m.fl. (1997) som studerar såväl amerikanska som svenska multinationella företag finner ett annat mönster än den tidigare litteraturen. För USA:s del dokumenterar de en klar nedgång i hemmasysselsättningen som en följd av växande aktiviteter i utvecklingsländerna. För Sveriges vidkommande finner de däremot rätt betydande positiva effekter, och notabelt även för arbetare i produktionen. Det bör dock noteras att den studerade perioden inte innefattar åren då investeringarna i de tidigare kommunistiska staterna i Baltikum,

\footnotetext{
${ }^{14}$ Ett exempel på en dylik undersökning är Stobaugh och Hayes (1976).
} 
öst-Asien eller Latin-Amerika har skjutit fart. En nyare studie (Braconier och Ekholm, 2000) som använder sig av svenska företagsdata som även innefattar denna period finner negativa sysselsättningseffekter. Men dessa avser produktion i höglöneländer. Expansion i låglöneländer har ingen effekt på hemmasysselsättningen. Det bör också nämnas att amerikanska studier som utnyttjat företagsdata (Brainard och Riker, 1997; Slaughter, 1995; 2000) i regel finner kvantitativt mindre effekter än undersökningarna som grundar sig på data på branschnivå.

En relativt färsk amerikansk undersökning för åren 1977-99 av Harrison m.fl. (2007) skiljer också mellan dotterföretag i höglöne- och låglöneländer. För de förstnämnda finner de för industrisektorns del att sambandet mellan sysselsättning i moder- och dotterföretaget är komplementärt medan motsvarande samband för dotterföretag i låglöneländer är negativt. Substitutionseffekten är emellertid förhållandevis låg, i synnerhet om vi tar i betraktande den betydande minskning $\mathrm{i}$ antalet arbetstillfällen inom industrin som ägt rum i USA under den studerade tidsperioden. Inom servicesektorn är det ovann"mnda sambandet komplementärt för dotterföretag i såväl högsom låglöneländer. Följaktligen har utflyttningen av industrijobb motverkats av en expansion av arbetstillfällen i servicenäringarna.

Tabell 5. Studier av effekterna av internationell utflyttning på arbetskraftsefterfrågan. Utflyttning på företagsnivå

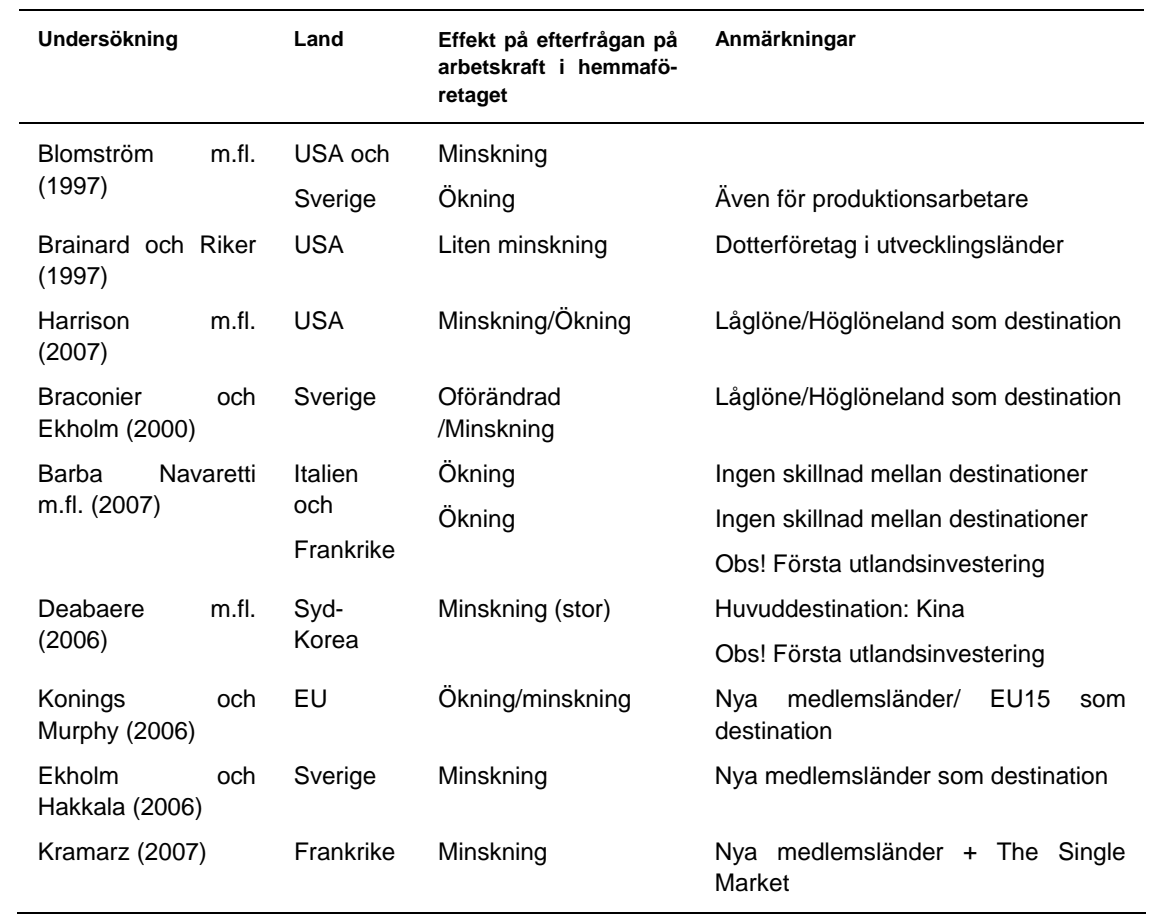

Två nyare undersökningar har studerat industriföretag som inte tidigare har genomfört direktinvesteringar i utlandet men nu väljer mellan att antingen fortsätta som tidigare eller att flytta ut produktion till ett annat land. Bägge analyserna skiljer mellan hög- och låglöneländer 
som destinationer för direktinvesteringarna. Barba Navaretti m.fl. (2007) har tillgång till två paneldatamängder; en för franska företag med fler än 20 anställda som investerar för första gången i utlandet under tidsperioden 1995 till 2000, och en annan som innehåller motsvarande information för italienska företag under perioden 1993-2001. Författarna finner att utlandsinvesteringarna har haft positiva effekter på produktionen och sysselsättningen i företaget i hemlandet både $\mathrm{i}$ Italien och Frankrike. Vidare finner de inga skillnader i dessa effekter mellan direktinvesteringar i hög- och låglöneländer.

Debaere m.fl. (2006) granskar också sysselsättningskonsekvenserna i hemmaföretaget när detta för första gången företar en direktinvestering i utlandet. Liksom i Barba Navaretti m.fl. (2007) är den "counterfactual”; man jämför med en situation där företaget väljer att fortsätta med att uteslutande producera i hemlandet. Debaere m.fl. (2006) använder sig av paneldata på börsnoterade sydkoreanska företag under tidsperioden 1980 till 1999. Utlandsinvesteringarna till låglöneländer har i SydKorea till övervägande delen företagits i Kina. Dessa visar sig ha haft en negativ effekt på sysselsättningstillväxten i hemmaföretaget. Investeringar i höglöneländer har däremot inte påverkat syssesättningsutvecklingen i hemmaföretaget. Detta mönster är förenligt med att de olika investeringsdestinationerna reflekterar olika mål med investeringarna; Kina och andra låglöneländer väljs när avsikten är att spara kostnader medan det huvudsakliga syftet med investeringar i höglöneländer är att söka och utvidga nya marknader. Det är dock notabelt att undersökningsresultaten för de franska och italienska företagen inte kommer fram till samma slutsatser trots att studierna i övrigt, vad gäller både data och metodval starkt påminner om varandra.

Ett problem i undersökningar av följdverkningarna av utflyttning av ett företags aktiviteter är att fastställa vad som skulle ha hänt om inte utflyttningen hade ägt rum. Man kan ofta föreställa sig olika kontrafaktuella förlopp. Ett är att investeringen skulle ha företagits av ett annat företag i stället. Hur hade i detta fall det studerade företagets konkurrensposition påverkats? Hade det kunnat fortsätta att producera mera i hemmaföretaget, eller hade ett annat inhemskt företag stått för den ökade produktionen? De ovan nämnda nyare studierna strävar till att mera explicit redovisa sina antaganden om de kontrafaktuella skeendena och utnyttjar sig även av statistiska tekniker (den så kallade propensity score matching-metoden) som bidrar till att göra meningsfulla jämförelser.

\subsection{Utvidgningen av EU}

Diskussionen om arbetsmarknadseffekterna av utvidgningen av EU har huvudsakligen gällt arbetskraftens rörlighet och detta återspeglar sig också i den europeiska arbetsmarknadsforskningen som under de senaste 
åren i hög grad fokuserat på invandringsfrågor och assimileringen av invandrarna på arbetsmarknaden. Ur ett nordiskt perspektiv förefaller det dock som minst lika motiverat att diskutera effekterna av utflyttningen av produktion till de baltiska länderna och Polen.

I samband med debatten om utvidgningen av EU framfördes ofta argumentet att investeringarna i de nya medlemsstaterna ägde rum i branscher som inte producerade för export (t.ex. kommunikation, energi och tjänster överhuvudtaget) och att syftet med investeringarna primärt var att lokalisera produktionen närmare de nya marknaderna snarare än att utnyttja möjligheterna att producera till avsevärt lägre kostnader. En studie av Konings och Murphy (2006) presenterar resultat som stöder denna argumentation. Sålunda visar deras studie att direktinvesteringar i de nya medlemsstaterna (med undantag för byggnadsbranschen och partihandel ${ }^{15}$ ) var förknippade med ökad sysselsättning i hemmaföretaget medan substitution mellan moder- och dotterföretaget fanns inom industrin och EU15-länderna. Studier för enskilda länder, såsom Ekholm och Hakkala (2006) för Sverige, Eriksson och Li (2006) för Danmark och Kramarz (2007) för Frankrike, finner emellertid klart negativa sysselsättningseffekter av produktion i de nya medlemsstaterna.

\subsection{Utrikeshandel och arbetskraftsefterfrågan}

Låt oss avsluta denna korta översikt av forskningen kring globaliseringens effekter på arbetsmarknaden genom att påpeka att utrikeshandeln förutom via en reallokering av produktionen även kan påverka sysselsättningen och dess struktur genom andra mekanismer. En under nittiotalet ofta framförd hypotes var att ökad internationell konkurrens på produktmarknaderna skapar en ökad press på de inhemska företagen att ändra sin produktsammansättning vilket i sin tur leder till att deras efterfrågan på mera kvalificerad arbetskraft växer. Tidigare empiriska studier av Berman m.fl. (1994) och Autor m.fl. (1998) finner emellertid inte stöd för denna hypotes. Men nyare forskning av Bernard m.fl. (2006) har visat att företagen anpassar sin produktmix till ökad importkonkurrens, i synnerhet när denna kommer från låglöneländerna.

Ovannämnda studier baserar sig på amerikanska data. I USA kan ökad importkonkurrens gå via lönerna varför konsekvenserna för sysselsättningen blir mindre. I Europa, och i Norden, har vi betydligt rigidare lönestrukturer och följaktligen kan den ökade internationella konkurrensen på produktmarknaden slå igenom på sysselsättningen. Denna hypotes bekräftas av Salvanes och Førres (2003) undersökning som använder sig av länkade employer-employee data från norsk industri. De finner att efterfrågan på kvalificerad arbetskraft inte har påverkats av den ökade utländska konkurrensen medan anställda med låg- eller mellanutbildnings-

\footnotetext{
${ }^{15}$ Det vill säga, man finner substitution i de branscher där man minst hade förväntat dem.
} 
nivå har påverkats negativt via en minskning i antalet jobb som förutsätter dessa kvalifikationer.

Även Biscourp och Kramarz (2007) erhåller liknande resultat för Frankrike. Deras studie är intressant för att de skiljer mellan slut- och mellanprodukter, olika konkurrensländer samt mellan kvalificerade/okvalificerade och produktions-/icke-produktions-arbetare. De finner att import av slutprodukter har större negativa effekter på antalet jobb än import av mellanprodukter. Vidare har import från låglöneländer endast en något större negativ effekt än från höglöneländer. Beträffande uppgraderingen av arbetskraftens kvalifikationer synes denna i Frankrike huvudsakligen äga rum inom företagen, inte som en process där ändringarna sker mellan företag.

\subsection{Sammanfattning}

Innan vi övergår till att presentera resultaten från våra egna studier skall vi kort sammanfatta de centrala punkterna i vår diskussion ovan. De är:

- Under de senaste årtiondena har det skett stora förändringar i den internationella handeln. Ur ett nordiskt perspektiv är två förändringar av synnerlig vikt: utvidgningen av EU till att omfatta de tidigare planekonomierna i central- och öst-Europa och integrationen av de stora starkt växande ekonomierna i öst-Asien. Samtidigt har utländskt ägande ökat avsevärt också i de nordiska länderna. Vidare har handeln med mellanprodukter vuxit kraftigt vilket reflekterar fragmenteringen av företagens värdekedjor.

- Betydelsen av dessa ändringar har (hittills) varit mest påtaglig inom industrisektorn, men utvecklingen kan mycket väl sprida sig i större utsträckning även till tjänstesektorerna.

- Den ekonomiska teorin för internationell handel befinner sig i en renoveringsfas som syftar till att beakta de nya mönstren och ändringarna i handeln.

- Möjligheterna att bedriva forskning om, liksom även bevakning av, internationaliseringen av företag och arbetsmarknader begränsas i hög grad av bristen på relevanta datamängder. Denna brist avspeglar den offentliga statistikproduktionens utpräglat nationella karaktär. Problemen med att mäta fenomenet internationalisering är också betydande.

- Den empiriska forskningskunskapen har hittills i hög grad baserat sig på indikatorer som beskriver utflyttning av företagens aktiviteter med hjälp av aggregerad information, vanligtvis på branschnivå. Flertalet av dessa studier visar att utflyttning av produktion och uppgifter leder till en ökad efterfrågan på mera kvalificerad arbetskraft samtidigt som sysselsättningsutsikterna för den okvalificerade arbetskraften försämras. Även löneskillnaderna mellan kvalificerad och okvalificerad 
arbetskraft tenderar att växa. Mönstret är det samma på bägge sidor av Atlanten, men omfattningen av effekterna är större i USA. Den stora utflyttningen av industriproduktion till Kina har i ännu högre grad påverkat industrisysselsättningen i de asiatiska grannländerna och förmodligen även Kinas främsta konkurrenter såsom Mexiko, LatinAmerika och Ryssland.

- Det föreligger anmärkningsvärt få studier som belyser effekterna av den ökade konkurrensen från de nya marknadsekonomierna i centraloch öst-Europa samt av utvidgningen av EU. Evidensen, som baserar sig på blott ett fåtal studier, är blandad; tidigare undersökningar fann positiva effekter på de gamla EU-länderna medan nyare studier pekar på klart mindre positiva och till och med negativa sysselsättningseffekter.

- Empirisk forskning som använder sig av information om företagens internationalisering vilken insamlats på företagsnivå är inte lika allmän och tecknar en mer varierande bild. Ett genomgående mönster är dock att tidigare studier fann positiva effekter på sysselsättningen i hemmaföretaget medan nyare undersökningar som även inkluderar ändringarna under det senaste decenniet finner mindre positiva, och ofta även negativa, effekter av utflyttningen på sysselsättning och löner i hemmaföretaget. Det förefaller även som om de mera aggregerade studierna ger resultat som tyder på en komplementär relation mellan sysselsättningen i moder- och dotterföretagen än studier som utnyttjar data som insamlats på företagsnivå. 


\section{Utlandsägda företag och de nordiska arbetsmarknaderna}

\subsection{Utlandsägda versus inhemska företag}

Det finns en rätt omfattande internationell litteratur om hur de multinationella företagen skiljer sig från de inhemskt ägda företagen. Den har dokumenterat att de utlandsägda företagen i regel är större, har en högre produktivitet (såväl arbets- som totalfaktorproduktivitet) samt betalar högre löner än de inhemska arbetsgivarna. Dessa egenskaper förklarar också varför multinationella företag är attraktiva och varför regionalpolitiska satsningar i flera länder har varit riktade mot dem. Irland är ett exempel på ett land som konsekvent och med stor framgång har strävat efter att locka till sig utländska direktinvesteringar och etableringar.

Orsakerna till varför utlandsägda företag är mera framgångsrika har dock endast delvis kunnat förklaras i forskningslitteraturen. Likaså är det alltjämt oklart huruvida det finns betydande spridningseffekter från de utlandsägda till de inhemska företagen; se Driffield och Taylor (2000). Vi har också förhållandevis begränsad kunskap om konsekvenserna för arbetsmarknaderna av en ökad etablering av utlandsägda företag. Det ovansagda gäller hela den internationella forskningen. Kunskapläget rörande de nordiska länderna är ännu mera bristfälligt.

I våra egna studier som utnyttjar sig av så kallade länkade data - dvs. data som innehåller såväl information om enskilda företag som deras anställda - finner vi också att de utlandsägda företagen i jämförelse med de inhemska företagen i genomsnitt har flera anställda, högre produktivitet, en högre andel högt utbildad arbetskraft samt högre löner (även vid given utbildning); se Tabell 6. Vi kan också notera att det finns vissa skillnader mellan de tre länderna. Eftersom Danmark har en klart annorlunda företagsstruktur än de övriga nordiska länderna - avsevärt färre stora företag - kommer skillnaderna i företagsstorlek att bli större här. Vidare kan vi lägga märke till att differenserna i andelen anställda med högre utbildning mellan utlands- och inhemskt ägda företag är mindre i Sverige än i Finland och Danmark.

Mönstret och storleksordningarna är i stort sett de samma som man funnit i studier för andra europeiska länder; jfr Conyon m.fl. (2002), Görg m.fl. (2002) och Martins (2004). För att förstå vad som ger upphov till dessa rätt stora skillnader i genomsnittstalen, använder vi oss av de detaljerade länkade databaserna för att utföra regressionsanalyser. Mera exakt 
skattar vi löneekvationer för ett urval av individer ${ }^{16}$ för att besvara frågan: kvarstår skillnaderna i lön och sysselsättning även när man kontrollerar för bransch-, företags- och individkaraktäristika? En annan fråga vi är intresserade av att belysa är: vad sker med sysselsättning, löner och kvalifikationsstrukturer i företag som uppköpts av utländska investorer?

Tabell 6. Skillnader mellan inhemska och utlandsägda företag i de nordiska länderna; genomsnitt för perioden 1992-2002

\begin{tabular}{|c|c|c|c|c|c|c|}
\hline \multirow[b]{2}{*}{ Antal anställda } & \multicolumn{2}{|c|}{$\begin{array}{l}\text { Danmark } \\
\text { Inh. Utl. }\end{array}$} & \multicolumn{2}{|c|}{$\begin{array}{l}\text { Finland } \\
\text { Inh. Utl. }\end{array}$} & \multicolumn{2}{|c|}{$\begin{array}{l}\text { Sverige } \\
\text { nh. Utl. }\end{array}$} \\
\hline & 21 & 68 & 275 & 255 & 269 & 294 \\
\hline $\begin{array}{l}\text { Arbetsprodukti- } \\
\text { vitet (index) }\end{array}$ & 100 & 141 & 100 & 129 & 100 & 128 \\
\hline $\begin{array}{l}\text { Andel med } \\
\text { högre ut- } \\
\text { bildning (\%) }\end{array}$ & 17 & 27 & 26 & 37 & 19 & 24 \\
\hline $\begin{array}{l}\text { Lön, grundut- } \\
\text { bildning (index) }\end{array}$ & 100 & 120 & 100 & 119 & 100 & 114 \\
\hline $\begin{array}{l}\text { Lön, högre } \\
\text { utbildning } \\
\text { (index) }\end{array}$ & 100 & 127 & 100 & 121 & 100 & 119 \\
\hline
\end{tabular}

Som framgår av Tabell 7a reduceras löneskillnaden för Danmarks vidkommande med cirka 30 procent (från 10,2 till 7,2 procent) när vi beaktar skillnader i humankapital och med 40 procent när vi beaktar differenser i branschtillhörighet och företagsegenskaper. (Inkluderas bägge samtidigt halveras löneskillnaden.) Utlandsägda företag är med andra ord koncentrerade till vissa branscher som betalar högre löner samt har vissa egenskaper (de är exempelvis större ${ }^{17}$ ) som är förknippade med högre löner också i inhemska företag.

\footnotetext{
${ }^{16}$ Flera tidigare studier har inte haft tillgång till individdata och har därför nödgats skatta effekten av utlandsägande på löner på företagsnivå. Man finner därvidlag avsevärt större skillnader i lön mellan utlandsoch inhemskt ägda företag än när man använder sig av individdata. Detta framgår synnerligen tydligt i en studie baserad på svenska data av Heyman m.fl. (2006) där författarna estimerar samma modell på samma data men med företag respektive individer som observationsenhet. Utlandspremien är 7,4 och 2,5 procent i estimationerna på företags- respektive individnivå. Motsvarande resultat har också erhållits i en annan studie för Sverige, Bandick (2008), som använder sig av samma data material men begränsar analysen till industrisektorn samt utnyttjar en annan definition av ett multinationellt företag än Heyman m.fl. (2006).

${ }^{17}$ Fördelningen enligt antalet anställda är synnerligen sned för de utlandsägda företagen. T.ex i Sverige har 86 procent av dem mindre än 50 medarbetare. De stora företagen är i gengäld verkligt stora. Sålunda sysselsätter fyra procent av dem mera än två tredjedelar av alla anställda i utlandsägda företag. (S2007:005)
} 
Tabell 7a. Skattningar av utlandsägande-lönpremier; Danmark 2002

\begin{tabular}{lrr}
\hline Förklaringsvariabler: & $\begin{array}{r}\text { Koefficient } \\
\text { (standardfel) }\end{array}$ & Korrig. $\mathbf{R}^{2}$ \\
\hline Utlandsägt företag & 0,102 & 0,007 \\
& $(0,0012)$ & \\
+ humankapital variabler & 0,072 & 0,357 \\
& $(0,0010)$ & \\
+ företagsstorlek och bransch & 0,064 & 0,114 \\
& $(0,0012)$ & \\
Alla ovan & 0,033 & 0,467 \\
+ a-kassamedlemskap, yrke, & $(0,0010)$ & \\
antal barn, Köpenhamnsdummy & &
\end{tabular}

När vi dessutom kontrollerar för skillnader i yrke och andra individkaraktäristika minskar löneskillnaderna mellan utlandsägda och inhemska företag ytterligare och ligger nu på 3 procent.

Motsvarande estimationsresultat för Sveriges del återges i Tabell $7 \mathrm{~b}$. Vi kan se (liksom även av Tabell 6) att den okorrigerade löneskillnaden mellan inhemska och utlandsägda företag är mindre i Sverige än i Danmark. De svenska skattningarna är emellertid inte direkt jämförbara enär de även innehåller en kontroll för branschtillhörighet. Hur som helst minskar också differensen i Sverige med cirka 40 procent när man tagit hänsyn till skillnaderna i kvalifikationsstrukturer hos företagens personal. Ytterligare kontrollvariabler som fångar upp skillnader i företagens kapitalintensitet och lönsamhet leder till enbart marginella ändringar i den skattade lönepremien för utlandsägande.

Tabell 7b. Skattningar av utlandsägande-lönpremier, Sverige 1996-2000

\begin{tabular}{lrr}
\hline Förklaringsvariabler: & $\begin{array}{r}\text { Koefficient } \\
\text { (standardfel) }\end{array}$ & Korrig. $\mathbf{R}^{2}$ \\
\hline Utlandsägt företag & 0,043 & 0,06 \\
& $(0,001)$ & \\
$+\quad$ humankapitalvariabler, & 0,026 & 0,42 \\
branschdummies & $(0,001)$ & \\
+ företagsstorlek, kapitalintensitet, & 0,025 & 0,45 \\
profitabilitet & $(0,000)$ & \\
\hline
\end{tabular}

Det är värt att notera att i dessa analyser jämförs de utlandsägda företagen med samtliga inhemska företag, även de inhemskt ägda multinationella företagen. När vi skiljer mellan rent inhemska företag och inhemskt ägda multinationella företag förändras bilden avsevärt. Detta är en av de viktiga poängerna i artikeln av Heyman m.fl. (2006). För Sverige kan vi nu (efter att ha kontrollerat för humankapital och företagskaraktäristika) observera en mycket liten skillnad i lön mellan utlandsägda företag och svenska multinationella företag: 0,4 procent. Differensen i förhållande till de inhemska företag som uteslutande är verksamma i Sverige blir nu 4,9 procent. Med 
andra ord finns det ingen nämnvärd skillnad i löner mellan inhemsk- och utlandsägda multinationella företag men nog mellan multinationella företag och företag som enbart verkar i Sverige.

Genomsnittslönen i danska multinationella företag är 22,8 procent högre än i rent danska företag utan aktiviteter i utlandet. De utlandsägda multinationella företagen betalar 9,9 procent högre löner än de danska multinationella företagen. Till en del återspeglar detta det faktum att de utlandsägda multinationella företagen i Danmark har en något större andel anställda med högre utbildning än de danska multinationella företagen. När vi genomför en liknande regressionsanalys som för de svenska data, krymper lönedifferensen mellan de utländska och inhemska multinationella företagen till 1,2 procent. De ovannämnda slutsatserna för Sverige gäller således även för Danmark.

Tabell 7c innehåller motsvarande skattningar för Finland. Dessa skiljer sig rätt markant från dem vi såg för Danmark och Sverige. Den okorrigerade lönedifferensen är större men reduceras ungefär lika mycket som i de andra länderna av att kontrollera för skillnader i humankapital. Företagskaraktäristika förefaller däremot att spela en större roll för att förklara skillnaderna i lön mellan inhemska och utlandsägda företag i Finland. Den löneskillnad som kvarstår efter att vi kontrollerat för såväl individ- som företagsegenskaper är också dubbelt så stor som i Danmark och Sverige.

Tabell 7c. Skattningar av utlandsägande-lönpremie, Finland 2002

\begin{tabular}{lrr}
\hline Förklaringsvariabler: & $\begin{array}{r}\text { Koefficient } \\
\text { (standardfel) }\end{array}$ & Korrig. $\mathbf{R}^{2}$ \\
\hline Utlandsägt företag & 0,231 & 0,02 \\
& $(0,003)$ & 0,27 \\
$+\quad$ humankapitalvariabler, & 0,152 & \\
branschdummies & $(0,003)$ & 0,34 \\
$+\quad$ företagsstorlek, kapitalintensitet, & 0,067 & \\
profitabilitet & $(0,003)$ & \\
\hline
\end{tabular}

Vi kan således konstatera att anställda i utlandsägda företag inte åtnjuter en betydande utlandsägarpremie, utan har huvudsakligen högre löner på grund av deras anställda besitter ett större humankapital. Däremot finns det en löneskillnad mellan multinationella (oavsett ägarnas nationalitet) och andra företag som inte helt och hållet kan tillskrivas skillnader i företagsstorlek, bransch eller arbetskraftens kvalifikationssstrukturer.

Beträffande effekterna på sysselsättning, löner och kvalifikationsstruktur i företag som köpts upp av utländska företag finner vi några intressanta resultat. Men innan vi diskuterar dem är det skäl att poängtera att det naturligvis inte är slumpmässigt vilka företag som blir uppköpta och att man är tvungen att ta hänsyn till denna omständighet i den statistiska analysen. Ifall att utländska investorer huvudsakligen köper upp synnerligen framgångsrika företag och om man inte kontrollerar för detta 
kan man lätt dra den felaktiga slutsatsen att uppköpta företag är väsentligt mera framgångsrika än andra företag.

I ljuset av våra analyser är det uppenbart att utländska ägare framför allt köper upp nordiska höglöneföretag och företag med en något större andel anställda med en högre utbildning. Härav kommer det sig följaktligen att lönerna är högre i de utlandsägda företagen.

Det är skäl att poängtera att vår diskussion hittills har gällt skillnader mellan inhemska och utlandsägda företag. En betydande del av utländska företag som är verksamma i de nordiska länderna har etablerat sig här genom uppköp av företag som ursprungligen hade inhemska ägare och i mindre utsträckning genom att starta upp ett dotterföretag från början (så kallade greenfield etableringar) ${ }^{18}$.

\subsection{Konsekvenserna av utländska företagsuppköp}

Det är kanske inte så överraskande att det finns skillnader mellan inhemska företag och företag som har startats upp som dotterbolag till ett utländskt, vanligtvis synnerligen framgångsrikt, multinationellt företag. Men vad sker i de nordiska företagen efter ett utländskt uppköp? Svaret på denna fråga är intressant av åtminstone två orsaker. Å ena sidan uttrycker deltagare i samhällsdebatten ofta farhågor om att de utländska ägarna tack vare att de är multinationella företag med verksamhet i flera länder kan ha en betydligt lägre tröskel än inhemska företag för att ta ett beslut om att flytta delar av produktionen till ett annat land, eller t.o.m. helt lägga ned den. I ekonomtermer betyder detta att ett ökat antal uppköp av nordiska företag leder till att arbetskraftsefterfrågan blir mera elastisk vilket för de anställda innebär en större osäkerhet $i$ anställningsförhållandena.

$\AA$ andra sidan är politiska beslutsfattare ofta intresserade av att locka utländska ägare till sina länder eftersom de utländska företagen förväntas ha positiva spillover-effekter på de inhemska företagen (i branschen, regionen eller landet). Dessa kan uppstå som en följd av att arbetskraften lär sig nya färdigheter (relaterade till bland annat teknologi, marknadsföring och ledningsmetoder) som de tar med sig när de flyttar till de inhemska företagen. Men man kan också tänka sig andra mekanismer; t.ex. att de inhemska företag som verkar som underleverantörer eller som kunder lär sig av de multinationella företagen och därigenom blir mer produktiva och effektiva.

Mot bakgrund av hur ofta dessa argument framförs i debatten är det anmärkningsvärt hur lite forskningsbaserad kunskap det finns som kan informera politiska beslutsfattare. De flesta studier som har utförts om de förväntade positiva spillover-effekterna undersöker hur förekomsten av multinationella företag inom en bransch påverkar de inhemska företagens

\footnotetext{
${ }^{18}$ Således hade enligt ITPS (2006) cirka 60 procent av de i Sverige verksamma utlandsägda företagen etablerats genom uppköp.
} 
produktivitet ${ }^{19}$. De kastar dock sällan ljus över vilka mekanismer som ger upphov till spillover-effekterna. De tidigare planekonomierna i centraloch öst-Europa utgör intressanta laboratorier för att studera spillovereffekter (i synnerhet till följd av överföring av ny kunskap) eftersom dessa inte innan övergången till marknadsekonomi tillät utländska investeringar. Studier för Bulgarien, Polen och Rumänien (Konings, 2001) samt för Litauen (Javroski, 2004) finner inga bevis respektive ytterst begränsad evidens för förekomsten av positiva spillover-effekter.

Under de allra senaste åren har forskare utnyttjat detaljerade s.k. linked employer-employee data till att studera dessa fenomen. Andrews m.fl. (2007) studerar effekterna av utlandsägande på de anställdas löner i Tyskland och finner att anställda som flyttar från ett inhemskt ägt företag till ett utlandsägt företag får en högre lön, medan lönen för anställda i utlandsägda företag som flyttar till ett inhemskt ägt företag inte påverkas i varken den ena eller den andra riktningen. Martins (2005) som utnyttjar liknande data från Portugal finner emellertid att anställda som flyttar från multinationella till inhemska företag i genomsnitt upplever en sänkning av sina löner.

Det finns två undersökningar som baserar sig på nordiska data. Balsvik (2006) använder sig av data från Norge och hon visar att mobilitet till de inhemskt ägda företagen är förknippad med en uppgång i de anställdas löner. Hon finner dessutom att rörlighet från utlandsägda till inhemska företag inom samma bransch har en positiv effekt på produktiviteten i de sistnämnda företagen. Enligt Balsviks (2006) statistiska analyser bidrar de anställda med erfarenhet från multinationella företag 20-25 procent mer än andra anställda till att höja produktiviteten i företagen de är anställda i.

Pesola (2007) använder länkade finska data och till skillnad från tidigare studier skiljer hon mellan arbetstagare med olika utbildningsbakgrund. Motivationen för detta är att den anställdas utbildningsnivå kan spela en roll för möjligheterna att lära sig och överföra ny kunskap från det multinationella till det inhemska företaget. Pesola finner liksom Balsvik att tidigare erfarenhet av arbete i ett multinationellt företag har en positiv löneeffekt när man senare övergår till att vara sysselsatt i ett inhemskt företag. Denna effekt är dock endast statistiskt säkerställd för individer med universitetsutbildning ${ }^{20}$.

Vi kan således konstatera att studierna hittills har kommit fram till rätt olika resultat beträffande effekterna av tidigare erfarenhet av anställning i multinationella företag på de anställdas löner. De två nordiska bidragen pekar dock bägge på en positiv effekt av arbetskraftsmobilitet mellan utlands- och inhemskt ägda företag på såväl de senares produktivitet som på lönen för den mobila arbetskraften. Man kan tänka sig att skillnaderna

\footnotetext{
${ }^{19}$ För analyser baserade på engelska och finska data, se Haskel m.fl. (2007) respektive Ilmakunnas och Maliranta (2004).

${ }^{20}$ Pesola (2007) undersöker också huruvida multinationella företag betalar för den kunskap tidigare anställda i inhemska företag tillför dem. Det gör de inte.
} 
i resultat mellan de nordiska och de andra studerade länderna beror att den nordiska arbetskraftens kvalifikationsnivå är högre och som följd därav kan den bättre utnyttja möjligheterna att överföra nya färdigheter och kunskaper till andra (dvs inhemska) företag.

Låt oss nu betrakta den forskningsevidens som finns vad gäller utlandsägandets effekter på arbetskraftsefterfrågan. Också här är litteraturen förhållandevis liten och av nyare datum ${ }^{21}$. Vidare använder sig en betydande del av studierna data på företagsnivå vilka dessutom huvudsakligen har hämtas från industrisektorn. En uppmärksammad studie är Barba Navaretti m.fl. (2003) som huvudsakligen jämför multinationella och inhemska företag med varandra med avsende på skillnader i anpassningen i arbetskraftsefterfrågan men som inte direkt baserar sig på observationer av ändringar i ägarskapet. Deras empiriska analyser av utländska dotterbolag i ett antal europeiska länder indikerar att arbetskraftsefterfrågan är mindre elastisk i dem än i de inhemska företagen.

Författarnas tolkning av detta resultat, som ju vederlägger det ovan nämnda argumentet att ökat ägande leder till större osäkerhet kring jobben, är att den lägre elasticiteten återspeglar det faktum att arbetsstyrkan i multinationella företag består av en klart större andel högt kvalificerade medarbetare, för vilka vi vet från annan forskning att efterfrågan är mindre känslig för variationer i löner och produktefterfrågan. Undersökningens resultat har följaktligen ifrågasatts. Så finner t.ex. Görg m.fl. (2006) i en studie baserad på data från Irland en väsentligt högre efterfrågeelasticitet i de utlandsägda företagen. En orsak till de starkt avvikande resultaten kan dock vara att företagsstrukturen på Irland avviker rätt markant från den kontinentaleuropeiska.

Två nya undersökningar på basen av data från den norska industrisektorn ger dock ett visst stöd för Barba Navarettis m.fl. (2003) resultat. Balsvik och Haller (2007) finner att utländska uppköp har en positiv effekt på den lokala produktiviteten medan utländska nyetableringar är förknippade med negativa effekter på den lokala produktiviteten. Nettoeffekten av närvaron av utländskt ägda företag är svagt positiv. I den andra studien visar Balsvik och Haller (2006) att utländska investerare, i motsats till vad som ofta hävdas i debatten, inte köper upp högproduktiva inhemska företag för att sedan avskeda en betydande del av deras personal. I själva verket vänder de utländska ägarna en negativ trend i såväl produktivitet som sysselsättning. Författarna visar att de utländska företagen i Norge under perioden 1992-97 hade en marknadsandel på 38 procent men stod för hela 61 procent av produktivitetstillväxten inom industrisektorn.

En nyare svensk undersökning av Hakkala m.fl. (2007) skiljer sig från de tidigare studierna i två avseenden. För det första skiljer den mellan effekten på efterfrågeelasticiteten av ägarskapet och av uppköpet. För det andra, jämför författarna multinationella företag med icke-multinationella

\footnotetext{
${ }^{21}$ Det finns en något mera omfattande litteratur kring relationen mellan ökad utrikeshandel och arbetskraftens efterfrågeelasticitet; se t.ex. Krishna m.fl. (2001) och Slaughter (2001).
} 
företag samt utlandsägda med inhemska företag. Vidare, eftersom de använder sig av länkade individ- och företagsdata, kan de även skilja mellan olika grupper av arbetstagare, framför allt med avseende på utbildning. Resultaten av deras analyser kan sammanfattas mycket kort: det finns inga skillnader i arbetsefterfrågans löneelasticitet mellan de olika företagstyperna.

Ett fåtal studier har undersökt sysselsättningskonsekvenserna i de uppköpta företagen. ${ }^{22}$ En italiensk studie av Piscitello och Rabbioso (2002) som begränsar sig till industrin finner att det utländska ägarskapet efter ett antal år medför såväl högre produktivitet som förbättrad sysselsättning i de berörda företagen. Girma och Görg (2004) finner det motsatta, nämligen att antalet sysselsatta i företag inom elektronik- och livsmedelsbranscherna i England sjönk efter att de blivit uppköpta av utländska ägare. Böckerman och Lehto (2006) har genomfört en undersökning som grundar sig på arbetsplatsdata från Finland och som gäller för både industri- och servicesektorerna. Deras tre huvudresultater är att: (1) utländska uppköp av industriföretag följs av sysselsättningsminskningar i desamma, (2) det uppstår betydande minskningar av sysselsättningen även inom byggnadsbranschen och servicenäringarna (men inte i handeln, hotelloch restaurang-branscherna), och (3) inhemska uppköp är förknippade med efterföljande minskningar i sysselsättningen i samtliga branscher. En annan finsk undersökning av Pesola (2007) vilken baserar sig på individdata finner att sysselsättningen på individnivå, mätt med sannolikheterna för att bli arbetslös, byta jobb eller utträda ur arbetskraften, påverkas negativt av utländska uppköp inom industrin. Däremot finner hon inga belägg för negativa effekter inom servicesektorn.

Tre tidigare studier har intresserat sig för hur utländska företagsförvärv påverkar arbetskraftens sammansättning i de uppköpta företagen: Almeida (2003), Lipsey och Sjöholm (2002) och Huttunen (2007). Den förstnämnda studerar utländska uppköp i Portugal och finner inga signifikanta ändringar i arbetskraftens kvalifikationsstruktur efter det att företaget fått nya ägare. Eftersom multinationella företag i regel har en mer kvalificerad arbetskraft skulle man förvänta sig att ett utländsk förvärv leder till en uppgradering av arbetskraftens utbildningsstruktur i de uppköpta företagen. Lipsey och Sjöholm som studerar uppköp i Indonesien finner belägg för detta antagande medan Huttunen som genomför en analys på finska data från industrisektorn för tidsperioden 1988-2001. Hon finner att andelen anställda med högre utbildning sjunker något som en följd av det utländska uppköpet.

Huttunens (2007) undersökning visar dessutom att det utländska förvärvet åtföljs av en positiv effekt på de anställdas löner. Effekten infinner

\footnotetext{
${ }^{22}$ Det finns rätt många studier som granskar hur nya ägare påverkar sysselsättningen i företagen men som inte skiljer mellan utländska och inhemska ägare. Två eksempel på undersökningar av detta slag som dessutom utnyttjar paneldata för individer är Margolis (2006) för Frankrike och Marsh m.fl. (2006) för Sverige. I bägge studierna tyder resultaten på att sannolikheten för arbetslöshet och mobilitet växer som en följd av de ändrade ägoförhållandena.
} 
sig dock inte omedelbart utan uppkommer gradvis under de efterföljande tre åren. Vidare är den positiva effekten på den anställdas lön större ju högre utbildningsnivå medarbetaren har. Därav följer att lönespridningen inom företaget växer som en konsekvens av att företaget fått nya utländska ägare.

En studie inom det aktuella projektet belyser också effekterna på lönespridningen inom de förvärvade företagen. Således dokumenterar Heyman m.fl. (2006) i sin undersökning av utländska uppköp av svenska företag i tidsperioden 1996 till 2000 två tydliga förändringar. Efter uppköpet är löneökningstakten något långsammare i de uppköpta företagen än i dem som stannat i inhemskt ägo. Samtidigt sker det en ändring i lönestrukturen; lönespridningen inom företaget växer och spridningen växer i synnerhet i den övre ändan av fördelningen. Det förefaller med andra ord som om speciellt företagsledningen gynnas lönemässigt av ett utländskt uppköp av företaget ${ }^{23}$. Även om man naturligtvis skall vara försiktig med att dra alltför starka slutsatser på basen av två studier - i synnerhet som den empiriska litteraturen kring utlandsägande och företagsuppköp synes ge rätt divergerande resultat - tyder undersökningarna på att de nordiska företagen med förhållandevis avancerade produktionsteknologier och en högt utbildad arbetskraft med internationellt sett låga löner är attraktiva uppköpsobjekt för utländska investerare och att detta i sin tur kan medverka till en tendens mot en ökad lönespridning.

\footnotetext{
${ }^{23}$ Notabelt är att det inte spelar någon roll om det uppköpta företaget är ett lokalt svenskt företag eller ett svenskt multinationellt företag. Detta indikerar att det är uppköpet i sig som ger upphov till den ökade spridningen, inte utlandsägandet.
} 



\section{Utflyttning av produktion - konsekvenser för sysselsättning och löner}

Det finns relativt lite tidigare forskning i Norden på detta område och det som finns kommer som vi har sett ovan huvudsakligen från Sverige. Nordisk forskning kring dessa frågor kämpar med samma problem som i de tidigare beskrivna internationella studierna: datamaterial som innehåller goda mått på utflyttning av företagens aktiviteter saknas och den information som finns, skiljer sig åt mellan länderna. Det går således inte, som så ofta annars är fallet, att genomföra komparativ forskning baserad på liknande data för de nordiska länderna.

Det är skäl att ännu en gång påminna om att det ofta finns flera samtidiga målsättningar med utflyttning av produktion än blott kostnadsbesparingar. Vidare är det högst sannolikt att många multinationella företag i dag i högre usträckning än tidigare har flera syften med sina utlandsetableringar. Det är också värt att notera att långt ifrån alla företag uppnår de målsättningar de har satt upp för sig med hjälp av utflyttningen av aktivieteterna. Således rapporterar Ali-Jyrkkö (2007) på basis av ETLA:s företagsenkät att något mindre än hälften av de finska företag ${ }^{24}$ som flyttat ut produktion till fullo uppnått de eftersträvade målen. Andelen är lägre (mellan 30 till 40 procent) vad gäller utflyttning av FoU-aktiviteter. I synnerhet förefaller det som om de åsyftade kostnadsbesparingarna och den eftersträvade närheten till kunderna och nya marknader uteblivit. Enligt en liknande dansk företagsenkät som genomförts av Dansk Industri (2003) bland dess medlemsföretag varierar erfarenheterna av produktion $\mathrm{i}$ utlandet rätt kraftigt. Sextio procent av de intervjuade företagen hade positiva erfarenheter (37 procent som förväntat och 22 bättre än som förväntat) medan en tredjedel uppgav att de var besvikna med utfallet. Fördelat på geografiska områden var graden av måluppfyllelse högre i de östasiatiska och östeuropeiska länderna.

Ett problem är som nämndes ovan att hämta fram information om utflyttning på företagsnivå. För detta ändamål är forskarna tvungna att utnyttja enkät- eller intervjuundersökningar riktade till företag. Detta har man gjort i Sverige sedan slutet av sjuttiotalet vid tidigare Industriens Utredningsinstitut (IUI), numera Institutet för Näringslivsforskning (IFN). Företagsurvalet består här av svenska multinationella företag. Detta datamaterial har använts i undersökningarna av Blomström m.fl. (1997), Braconier

\footnotetext{
${ }^{24}$ Teknologiföretagen rappporterar något större framgångar än övriga industriföretag.
} 
och Ekholm (2000) och Ekholm och Hakkala (2006) som vi diskuterade i översikten ovan.

I det följande redogörs kort för en undersökning, Eriksson och $\mathrm{Li}$ (2006), som utförts som en del av det aktuella projektet med hjälp av data från Danmark vilka konstruerats genom att länka två företagssurveys som genomförts av Dansk Industri (en dansk intresseorganisation för danska industriföretag) och som fokuserar på företagens utflyttningsaktiviteter till en företagsdatabas samt till ett registerdatamaterial i Danmarks Statistik, benämnt IDA, som innehåller detaljerad, longitudinell arbetsmarknadsinformation rörande samtliga anställda i de intervjuade företagen.

Analysen syftar till att belysa effekterna av utflyttning på sysselsättning och löner i hemmaföretaget. För detta ändamål estimeras först en liknande regressionsmodell som i Blomström m.fl. (1997) med sysselsättningen i hemmaföretaget som beroende variabel, omsättningen i hemmaföretaget som kontrollvariabel samt omsättningen (alternativt produktionen) i utlandet som den centrala förklaringsvariabeln. Analysen genomförs för två år: 1997 och 2002. Valet av dessa år betingas av att dessa är de två senaste åren företagssurveyen har genomförts. Författarna studerar effekten av ändringar i utländsk produktion (eller omsättning) på den totala sysselsättningen i hemmaföretaget men också på hemmasysselsättningen uppdelad enligt de anställdas utbildning eller jobbfunktioner. Vidare skiljer man mellan utländsk produktion i utvecklade ekonomier, central- och öst-Europa samt utvecklingsekonomier. De statistiska analysresultaten sammanfattas i tabellerna 8 och 9.

Tabell 8. Modell för sysselsättningen i hemmaföretaget

\begin{tabular}{|c|c|c|c|c|c|}
\hline & & 1997 & 1997 & 2002 & 2002 \\
\hline $\begin{array}{l}\text { Omsättning } \\
\text { Danmark }\end{array}$ & i & $0,33^{\star \star *}$ & $0,62^{\star \star * *}$ & $0,34^{* * *}$ & $0,42^{\star * \star}$ \\
\hline $\begin{array}{l}\text { Omsättning } \\
\text { utlandet }\end{array}$ & $\mathrm{i}$ & $0,24^{\star \star \star}$ & & $0,047^{\star \star *}$ & \\
\hline $\begin{array}{l}\text { Produktion } \\
\text { utlandet }\end{array}$ & i & & 0,064 & & $0,038^{\star \star \star}$ \\
\hline Korrig. $\mathrm{R}^{2}$ & & 0,96 & 0,95 & 0,66 & 0,61 \\
\hline
\end{tabular}

Not: 1 procents signifikansnivån anges med ***

Av tabellerna kan vi se att en större omsättning (produktion) i utlandet, vid given inhemsk omsättning, leder till en större total sysselsättning i hemmaföretaget. Samma resultat erhålles även när man skiljer mellan olika utbildningskategorier eller olika jobbfunktioner. De positiva sysselsättningseffekterna är dock betydligt mindre år 2002.

När vi disaggregerar förklaringsvariabeln enligt geografisk placering (se Tabell 9), vilket dessvärre enbart kan göras för år 2002, erhåller vi annorlunda resultat. Större utlandsaktiviteter i utvecklade industri-länder är alltjämt förknippade med ett större antal anställda i hemmaföretaget. Ökad utflyttning av aktiviteter till central- och öst-Europa samt till utvecklingsländer (dvs. huvudsakligen öst-Asien) är däremot förbunden 
med negativa sysselsättningseffekter. Såsom framgår av den femte kolumnen i tabell 9 är den negativa effekten på den totala hemmasysselsättningen är klart större för utflyttning till central- och öst-Europa. Koefficientskattningarna tyder på att en given öknng av omsättningen i centraloch öst-Europa har en fem gånger större negativ effekt på hemmasysselsättningen än motsvarande ökning av omsättningen i ett utvecklingsland.

En vidare uppdelning av hemmasysselsättningen i jobb-funktioner implikerar bl.a. att anställda i produktionen drabbas av ökad utflyttning till utvecklingsländer. Sammantagna tyder dessa resultat på att effekterna av utflyttning ändrats över tiden allt eftersom en större andel av den sker till länder med avsevärt lägre löner än i Danmark. De tidigare, övervägande positiva, effekterna försvagas och om de senare årens trend mot en allt större utflyttning av produktion till låglöneländer fortsätter, får de negativa effekterna allt större betydelse och kan t.o.m. komma att dominera.

Eriksson och Li (2006) gör även ett försök att kasta ljus över om och i vilken utsträckning lönerna för de sysselsatta i hemmaföretaget påverkas av utflyttningsaktiviteterna. För detta ändamål skattar de löneekvationer för individer i fyra olika tvärsnittssampel (åren 1990, 1993, 1997, 2002) bestående av sysselsatta i företag som både har och inte har aktiviteter i utlandet. Utöver de sedvanliga förklaringsvariablerna i modeller som syftar till att förklara individuella löneskillnader (ålder, kön, utbildning, anciennitet, bransch, m.m.) inkluderas även andelen sysselsatta i företaget utanför Danmarks gränser. Notera att för många av de studerade individerna (företagen) är denna andel lika med noll.

Tabell 9. Modeller för sysselsättningen i hemmaföretaget enligt funktion och enligt grupper av destinationsländer för utflyttningsaktiviteterna

\begin{tabular}{|c|c|c|c|c|c|}
\hline $\begin{array}{l}\text { Hemma- } \\
\text { sysselsättning: }\end{array}$ & $\begin{array}{r}\text { Omsättning i } \\
\text { Danmark }\end{array}$ & $\begin{array}{r}\text { Omsättning } \\
\text { i utvecklade } \\
\text { länder }\end{array}$ & $\begin{array}{r}\text { Omsättning i } \\
\text { utvecklings- } \\
\text { länder }\end{array}$ & $\begin{array}{c}\text { Omsättning i } \\
\text { central- och } \\
\text { öst-Europa }\end{array}$ & $\begin{array}{r}\text { Korrig. } \\
\mathbf{R}^{2}\end{array}$ \\
\hline Alla & $0,67^{\star \star \star}$ & $0,29 * * *$ & $-0,42^{*}$ & $-2,05^{\star \star \star}$ & 0,96 \\
\hline $\begin{array}{l}\text { Administration } \\
\text { och ledning }\end{array}$ & $0,068^{\star \star \star}$ & $0,089 * \star \star$ & $-0,043$ & 0,232 & 0,61 \\
\hline Produktion & 0,330 *** & $0,280^{\star * *}$ & $-0,501$ & $-0,091$ & 0,79 \\
\hline Service & $0,062^{\star \star \star}$ & 0,003 & 0,013 & $-0,064$ & 0,23 \\
\hline Försäljning & $0,066^{\star \star \star}$ & $0,024^{\star * *}$ & $-0,039$ & 0,052 & 0,70 \\
\hline F\&U & $0,050^{\star * *}$ & $0,060 * \star \star$ & $-0,131^{\star \star}$ & $-0,112$ & 0,71 \\
\hline
\end{tabular}

Not:10, 5 och 1 priocents signifikansnivåerna anges med *, ** repektive ***

Tabell 10 återger koefficientskattningarna för den centrala förklaringsvariabeln: andelen sysselsatta utanför landets gränser. Vi kan se att löneskillnaderna mellan utlandsaktiva och -passiva företag har ändrat sig över tiden. I början av perioden är differenserna små, men i slutet av perioden har de vuxit och är nu klart större. Vi kan också notera att lågt utbildade anställda i danska företag med betydande produktion i utlandet har allt annat lika lägre löner än andra lågt utbildade löntagare. Vi kan bara spekulera om orsakerna till detta men en huvudkandidat torde vara att de 
anställda i företag med betydande aktiviteter i utlandet har en svagare position i förhandlingar om lön. Allt som allt tyder dessa resultat på att även lönerna påverkas av företagens utflyttningsaktiviteter och att lågt kvalificerade anställda förefaller att ha varit den grupp som har påverkats mest.

Tabell 10. Koefficientestimat till variabeln "andel av sysselsatta i företaget utanför landets gränser"

\begin{tabular}{lrrrr}
\hline $\begin{array}{l}\text { Sysselsättnings- } \\
\text { kategori: }\end{array}$ & 1990 & 1993 & 1996 & 2002 \\
\hline Alla anställda & $-0,032$ & 0,013 & 0,34 & $-0,029$ \\
& $(0,006)$ & $(0,006)$ & $(0,005)$ & $(0,008)$ \\
Enligt utbildning: & & & \\
Låg nivå & 0,000 & 0,056 & 0,036 & $-0,027$ \\
& $(0,009)$ & $(0,009)$ & $(0,008)$ & $(0,012)$ \\
Mellannivå & $-0,059$ & $-0,004$ & 0,020 & $-0,058$ \\
& $(0,008)$ & $(0,009)$ & $(0,008)$ & $(0,011)$ \\
Hög nivå & 0,005 & 0,017 & 0,054 & 0,061 \\
& $(0,015)$ & $(0,015)$ & $(0,014)$ & $(0,021)$ \\
\hline
\end{tabular}




\section{Avslutande kommentarer}

I det följande sammanfattas de centrala resultaten av de föregående avsnitten. Eventuella politikimplikationer diskuteras också:

- Utlandsägda företag förefaller inte att betala en särskild lönepremie till sina anställda men anställer medarbetare med högre kvalifikationer och utbild ning än inhemska företag. Hur det växande utländska ägandet påverkat arbetsmarknaderna är alltjämt en öppen fråga. Det finns emellertid indikationer på att en av konsekvenserna kan vara ökade löneskillnader, speciellt i den övre ändan av den företagsinterna lönefördelningen.

- En viktig insikt från de genomförda analyserna är att de utländska multinationella företagen inte nämnvärt skiljer sig från de inhemska multinationella företagen med avseende på hur de avlönar sina anställda, arbetskraftens kvalifikationsstruktur, m.m. Den centrala distinktionen är mellan multinationella och icke multinationella företag, inte mellan inhemskt och utlandsägda företag.

- Det finns inget helt entydigt svar på frågan huruvida ett ökat antal uppköp av nordiska företag innebär att arbetskraftsefterfrågan blir mer elastisk och därmed skapar ökad otrygghet för de anställda. Men de fåtaliga nordiska studierna tyder faktiskt på att det antingen förhåller sig omvänt (dvs. efterfrågeelasticiteten är lägre i de utlandsägda företagen) eller så finns det ingen skillnad mellan inhemska, utlands- och inhemskt ägda multinationella företag.

- En annan intressant fråga är huruvida de utländska företagen har positiva spillover-effekter på de inhemska företagen och deras anställda. Den internationella litteraturen, som är rätt liten, pekar i alla möjliga riktningar medan de nordiska bidragen, som det skall understrykas är synnerligen få till antalet, tecknar en mera entydigt positiv bild: erfarenhet av arbete i ett mutinationellt företag ger högre lön (och högre produktivitet) vid anställningar i inhemska företag. Detta tyder på att det finns positiva spillover-effekter i de nordiska länderna.

- Forskningen om konsekvenserna för sysselsättningen och dess struktur av ett utländskt uppköp är fortfarande för ung för att man skall kunna dra långtgående slutsatser.

- Resultaten från forskningen om utflyttningens effekter på sysselsättningen i hemmaföretaget eller den lokala arbetsmarknaden pekar också i rätt divergerande riktningar. Det är dock inte helt oväntat att effekterna kan ändra sig över tiden eftersom utflyttningens drivkrafter och därmed destinationer (och form) har ändrats väsentligt 
under de senaste decennierna. Ett mönster som kan skönjas i den nyare forskningen, och som även finner stöd i våra egna bidrag, är att de positiva sysselsättningseffekterna i hemlandet har blivit mindre och till och med negativa.

- Många iakttagare och kommentatorer av globali-seringsprocessernas inverkan på arbetsmarknaderna har understrukit att effekterna är av relativt blygsam omfattning. Sålunda framhävs det ofta i diskussionen att antalet arbetstillfällen som går förlorade till följd av utflyttningar av produktion och tjänster till andra länder är relativt litet i jämförelse med det totala antalet arbetstillfällen som försvinner i loppet av ett år. Det saknas inte heller exempel på branscher eller lokala arbetsmarknader där utlandsinvesteringarna har haft en gynnsam effekt på sysselsättningen. Men även i dessa situationer förekommer det betydande förluster av arbetstillfällen och de samhällsekonomiska kostnaderna av de nödvändiga omställningarna kan inte förbises i en värdering av den sammanlagda effekten på ekonomin. Dessa anpassningsprocesser kan bli mera smärtsamma i samhällen som det amerikanska som av tradition saknar arbetsmarknadspolitiska institutioner för att underlätta omvandlingsprocesserna. Denna form av mekanismer har vi haft i de nordiska länderna och de medverkade också till att underlätta strukturomvandlingen under sextio- och sjuttiotalen. Det kan mycket väl vara att dessa igen kan komma att efterfrågas i högre grad än under de senaste decennierna. Förekomsten av dessa politikinstrument kan också delvis förklara varför man i de nordiska länderna i flera internationella jämförelser är mindre bekymrad över internationaliseringens effekter på arbetsmarknaden.

\section{Litteratur}

Ali-Yrkkö J (2006), Ulkoistus ja toimintojen siirrot ulkomaille - katsaus 2000-luvun alun tilanteesta. ETLAn keskustelualoitteita no 1052

Ali-Yrkkö J (2007), Tuotannon ja T\&K-toiminnan ulkoistaminen - motiivit ja onnistuminen. ETLAn keskustelualoitteita no 1071

Almeida R (2003), The Effects of Foreign Owned Firms in the Labor Market. IZA DP No. 785

Amiti M och S-J Wei (2005), Fear of Service Outsourcing. Economic Policy, April 2005, 307-347

Andrews M, L Bellman, T Schank och R Upward (2007), The takeover and Selection effects of Foreign Owner- ship in Germany. University of Nottingham GEP Research Paper 8/2007 Autor D, L Katz och A Krueger (1998), Computing Inequality: Have Computers Changed the Labor Market? Quarterly Journal of Economics 113, 1169-1213

Baghwati J, A Panagariya och T Srinivasan (2005), The Muddles over Outsourcing. Journal of Economic Perspectives 18, 93-11

Balsvik R (2006), Is Mobility of Labour a Channel for Spillovers from Multinationals to Local Domestic Firms? NHH, Department of Economics DP No. 25/06 
Balsvik R och S Haller (2006), The Contribution of Foreign Entrants to Employment and Productivity Growth. ESRI Discussion Paper 26/2006

Balsvik R och S Haller (2007), Foreign Firms and Host-Country Productivity: Does the Mode of Entry Matter? NHH Discussion Paper SAM 2, 2006

Bandick R (2008), Is It Profitable to Work for Multinationals in Sweden? Opublicerad uppsats, Universitet i Örebro

Barba Navaretti G, D Castellani och AC Disdier (2006), How Does Investing in Cheap Labour Countries Affect Performance at Home? France and Italy. Centro Studi Luca D'Agliano working paper 215

Barba Navaretti G, D Checchi och A Turini (2003), Adjusting Labor Demand: Multinational versus National Firms: A Cross-European Analysis. Journal of the European Economic Association 1, 708-719

Berman E, J Bound och Z Griliches (1994), Changes in the Demand for Skilled Labor within U.S. Manufacturing: Evidence from the Annual survey of Manufactures. Quarterly Journal of Economics 104, 367-398

Bernard A, J Jensen and P Schott (2006), Survival of the Best Fit: Exposure to Low-Wage Countries. Journal of International Economics 68, 219-237

Biscourp P och F Kramarz (2007), Employment, Skill Structure and International Trade: Firm-level Evidence for France. Journal of International Economics 72, 22-51

Blinder A (2006), Offshoring: The Next Industrial Revolution? Foreign Affairs, March/April

Blinder A (2007), How Many U.S. Jobs Might Be Offshorable? Princeton University, CEPS Working Paper No. 142

Blomström M, G Fors och R Lipsey (1997), Foreign Direct Investment and Employment: Home Country Experience in the United States and Sweden. Economic Journal 107, 1787-1797

Braconier J och K Ekholm (2000), Swedish Multinationals and Competition from High- and Low-wage Loca- tions. Review of International Economics 8, 448-461

Brainard L och D Riker (1997), Are U.S. Multinationals Exporting U.S. Jobs? NBER working paper 5958

Böckerman P och E Lehto (2006), Enemy of Labour? Analysing the Employment Effects of Mergers and Acquisitions. PT Discussion Papers 221, Helsinki (under publicering i Journal of Economic Behavior \& Organization)

Conyon M, S Girma, S Thompson og P Wright (2002), The Productivity and Wage Effects of Foreign Acquisition in the United Kingdom. Journal of Industrial Economics L, 85-102

Dansk Industri (2003), Etableringsundersøgelsen 2003. København

Debaere P, H Lee och J Lee (2006), Does Wheer You Go Matter? The Impact of Outward Foreign Direct Investment on Multinationals' Employment at Home. CEPR Discussion Paper No. 5737

Driffield N och K Taylor (2000), FDI and the Labour Market: A Review of the Evidence and Policy Implications. Oxford Review of Economic Policy 16, 90-103

Ekholm K och K Hakkala (2006), The Effect of Offshoring on Labour Demand: Evidence from Sweden. CEPR Discussion Paper 5648

Eriksson T och J Li (2006), The Effects of the Internationalization of Danish Enterprises on Home Employment and Wages: Analysis of Firm Data. ASB working paper

Falk M och B Kobel (2002), Outsourcing, Imports and Labour Demand. Scandinavian Journal of Economics 104, 567-586

Feenstra R och G Hanson (1996), Foreign Investment, Outsourcing and Relative Wages, I: R Feenstra, G Grossman och D Irwin (red.), The Political Economy of Trade Policy. Papers in Honor of Jagdish Bhagwati. MIT Press

Feenstra R och G Hanson (1999), Productivity Measurement and the Impact of Trade and Technology on Wage Estimates for the U.S., 19721990. Quarterly Journal of Economics 114, 907-940

Feenstra R och G Hanson (2003), Global Production Sharing and Rising 
Inequality. A Survey of Trade and Wages. I: E Choi och J Harrigan (red.), Handbook of International Trade. Blackwell Publishers; London Freeman R (1995), Are Your Wages Set in Beijing? Journal of Economic Perspectives $9,15-32$

Freeman R (2005), China, India and the Doubling of the Global Labor Force. The Globalist, June 2005

Geishecker I och H Görg (2004), Winners and Losers: A Micro-level Analysis of International Outsourcing and Wages. Canadian Journal of Economics 41, 243-270

Girma S och H Görg (2004), Blessing or Curse? Domestic Plants' Employment and Survival Prospects after Foreign Acquisition. Applied Economics Quarterly 50, 89-110

Golub S (2003), Measures of Restrictions on Inward Foreign Direct Investment for OECD Countries. OECD Economic Studies No. 36

Görg H, M Henry, E Strobl och F Walsh (2006), Multinational Companies, Backward Linkages and Labour demand elasticities. Univeristy of Nottingham, GEP Research Paper No. 49

Görg H, E Strobl och F Walsh (2002), Why Do Foreign-owned Firms Pay More? The Role of On-the-job Training. Discussion Paper, University of Nottingham

Hakkala K, F Heyman och F Sjöholm (2007), Cross-Border Acquisitions, Multinationals and Wage Elasticities. IFN, manuskript

Hansson P (2005), Skill Upgrading and Production Transfer within Swedish Multinationals. Scandinavian Journal of Economics 107, 673-692

Harrison A, M McMillan och C Null (2007), U.S. Multinational Activity Abroad and U.S. Jobs: Substitutes or Complements? Industrial Relations 46, 347-365

Haskel J, S Pereira och M Slaughter (2007), Does Inward Foreign Direct Investment Boost the Productivity of Domestic Firms? Review of Economics and Statistics 89, 482-496

Head K och J Ries (2002), Offshore Production and Skill Upgrading by Japanese Manufacturing Firms. Journal of International Economics 55, 81-105
Heyman F, F Sjöholm och P Gustafsson Tingvall (2006), Acquisitions, Multinationals and Wage Dispersion. Research Institute of Industrial Economics, Working Paper No. 675

Heyman F, F Sjöholm och P Gustafsson Tingvall (2006), Is There Really a Foreign Ownership Wage Premium: Evidence from Matched EmployerEmployee Data. Utkommer i Journal of International Economics

Hijzen A, H Görg och R Hine (2005), International Outsourcing and the Skill Structure of Labour Demand in the United Kingdom. Economic Journal 115, 861-879

Hsie C-T och K Woo (2005), The Impact of Outsourcing to China on Hong Kong's Labor Market. American Economic Review 95, 1673-1687

Hummels D, J Ishii och K-J Yi (2001), The Nature and Growth of Vertical Specialization in World Trade. Journal of International Economics 54, 75-96

Huttunen K (2007), The Effect of Foreign Acquisition on Employment and wages: Evidence from Finnish Manufacturing. Review of Economics and Statistics 89, 497-509

Ilmakunnas P och M Maliranta (2004), Foreign Medicine: A Treatment effect Analysis of the Productivity Effects of Foreign Ownership. Applied Economics Quarterly 50, 41-60

Javorcik B (2004), Does Foreign Direct Investment Increase the Productivity of Domestic Firms? In Search for Spillovers Through Backward Linkages. American Economic Review 94, 605-627

Jensen B och L Kletzer (2005), Tradable Services: Understanding the Scope and Impact of Services Offshoring, in: L Brainard and S Collins (eds.), Brookings Trade Forum 2005, Offshoring White-Collar Work - The Issues and the Implications. Brookings Institution

Konings J (2001), The Effects of Foreign Direct Investment on Domestic Firms. Economics of Transition 9, 619-633

Konings J och A Murphy (2006), Do Multinational Enterprises Substitute Parent Jobs for Foreign Ones? Evidence from European Firm-Level 
Data. Review of World Economics 142, 1-20

Krishna P, M Devavish och S Chinoy (2001), Trade Liberalization and Labour Demand Elasticities: Evidence from Turkey. Journal of International Economics 55, 391-409

Kramarz F (2006), Outsourcing, Unions, and Wages: Evidence from Data Matching Imports, Firms, and Workers. CREST-INSEE working paper

Lipsey R och F Sjöholm (2004), FDI and Wage Spillovers in Indonesian Manufacturing. Review of World Economics 134, 321-332

Marsh J, D Siegel och K Simons (2006), Analysing the Effects of Ownership Change on Women and Minority Employees: Evidence from Matched Employer-Employee Data. Rensselaer Working Papers in Economics No. 0607

Martins P (2004), Do Foreign Firms Really Pay Higher Wages? Evidence from Different Estimators. IZA Discussion Paper No. 1388

Martins P (2006), Inter-firm Mobility, Displacement, and Foreign Direct Investment Spillovers. Queen Mary College, working paper

OECD (2003), Statistics on Measuring Globalisation, 2003. OECD; Paris

Pesola H (2007), Individual Level Employment Effects of Foreign Acquisitions. Helsinki School of Economics working paper

Pesola H (2007), Foreign Ownership, Labour Mobility and Wages. HECER Discussion Paper No. 175

Rosholm M, A Scheuer och A Sørensen A (2007), The Implications of globalization for Firms' Demand for Skilled and Unskilled Labor. CEBR, manuscript

Salvanes K och S Førre (2003), Effects on Employment of Trade and Techni- cal Change: Evidence from Norway. Economica 70, 293-329

Slaughter M (1995), Multinational Corporations, Outsourcing, and American Wage Divergence. NBER working paper 5253

Slaughter M (2000), Production Transfer within Multinational Enterprises and American Wages. Journal of International Economics 50, 449-472

Slaughter M (2001), International Trade and Labor Demand Elasticities. Journal of International Economics 54, 27-56

Spencer B (2005), International Outsourcing and Incomplete Contracts. NBER working paper 11418

Stobaugh R och R Hayes (1976), Nine Investments Abroad and their Impact at Home: Case Studies on Multinational Enterprises and the US Economy. Harvard Business School Press; Boston

Strauss-Kahn V (2003), The Role of Globalization in the Within-Industry Shift Away from Unskilled Workers in France. i: R Baldwin and A Winters (eds.), Challenges to Globalization: Analyzing the Economics. NBER and University of Chicago Press; Chicago

Swedenborg B (1979), The Multinational Operations of Swedish Firms: An Analysis of Determinants and Effects. IUI; Stockholm

Sørensen A och J Skaksen (2005), Capital-Skill Complementarity and Rigid Relative Wages: Inference from the Business Cycle. Contributions to Macroeconomics, Vol. 5

Yeh R och H Lin (2006), The Effects of FDI Location Choices on the Home Economy: A Firm Level Analysis. National Chi-Nan University working paper 